\title{
The Very Grounds Underlying Twentieth-Century Authoritarian Regimes: Building Soil Fertility in Italian Libya and the Brazilian Cerrado
}

\author{
ROBERTA BIASILLO
}

Robert Schuman Centre for Advanced Studies, European University Institute, San Domenico di Fiesole, Italy

\section{CLAITON MARCIO DA SILVA}

Department of History, Universidade Federal da Fronteira Sul, Santa Catarina, Brazil

\section{A TALE OF FOUR CONTINENTS}

Comparing Italy and Brazil on the grounds of the authoritarian quality of their regimes is hardly new. In the decades before 1945, the two countries lived with authoritarian governments and several studies have examined the circulation of Italian Fascist ideas and the myth of Mussolini's personality in Latin America. ${ }^{1}$ Italian Fascism influenced the development of the Brazilian authoritarian system and represented one of the pillars of the so-called Vargas Era

Acknowledgments: The authors wish to thank Marco Armiero, Tanya Rahman, and Daniele Valisena for the comments they provided at different stages of writing this paper. They are also grateful to the anonymous $C S S H$ reviewers for their encouraging tone and thorough feedback. Italian and Brazilian sources and texts have been translated by the authors.

1 M. Mugnaini, “L'Italia e l'America Latina (1930-1936): alcuni aspetti della politica estera fascista," Storia delle relazione internazionali 2 (1986): 199-44; M. Mugnaini, L'America Latina e Mussolini: Brasile e Argentina nella politica estera dell'Italia (1919-1943) (Milano, 2008); M. G. Losano, "Un modello italiano per l'economia nel Brasile di Getúlio Vargas: la 'Carta del Lavoro' del 1927,' Rechtsgeschichte-Legal History 20 (2012): 274-308; F. Gentile, "Il Brasile e il modello del corporativismo fascista," Passato e Presente 91 (2013): 35-58; F. Gentile, "Oliveira Vianna teorico del corporativismo fascista nel Brasile dell "Era Vargas,", Ricerche di storia politica 3 (2017): 273-93; M. Feldman, J. Dagnino, and P. Stocker, eds., The "New Man" in Radical Right Ideology and Practice, 1915-45 (London, 2018), esp. chs. 2 and 8. 
between the Revolution of 1930 and end of World War II. Within this comparative framework, attention has also been drawn to agricultural and urban issues. ${ }^{2}$ Building on this comparative perspective, our paper shifts the focus from the similarities between Benito Mussolini's and Getúlio Vargas' regimes to examine how authoritarian governments in Italy and Brazil, in different time periods, have approached the specific issue of soil fertility and produced "improved" soils, from both political and technological perspectives. In other words, while the development of fascist regimes has been a hallmark of comparative analyses of the history of these two countries, we stretch this correlation further by extending its timeframe and redirecting its scope.

This paper will address a set of interrelated research questions: What kind of soil-based socio-ecologies have mirrored the twentieth-century authoritarian regimes? What can be historically inferred about dictatorships by analyzing trends of soil fertility? How did scientific expertise and political propaganda envision and transform arid soils in order to nurture and serve dictatorial power? Can we consider fertility an indicating factor in measuring the success or failure of both an ecological scheme and a political regime?

We argue that this exploration of the role played by agriculture in Italy and Brazil under the Fascist and civil-military dictatorships, respectively, demonstrates the ubiquitous, co-constitutive relationship between soil fertility and all dictatorial regimes, no matter when or where they unfold. To illustrate and implement our argument we rely on secondary literature and analyze two precise wheres and whens: North Libya under Italian Fascist rule from 1922-1943 and Central Brazil under the civil-military dictatorship from 1964-1985.

The coastal areas of Tripolitania and Cyrenaica (part of modern-day Libya), especially after the 1932 military "reconquest,"3 provide an excellent case for demonstrating how land and politics can intertwine. Firstly, in colonizers' portrayals, the building of a fascist Italian Libya made a case for a state-driven demographic colonization via agriculture. Secondly, Libya speaks to fascist politics in general-encompassing imperial ambitionssince it synthesized internal and external colonization: ${ }^{4}$ it was an in-between

2 R. S. Seitenfus, "Ideology and Diplomacy: Italian Fascism and Brazil (1935-38)," Hispanic American Historical Review 64, 3 (1984): 503-34; M. D’Ayala Valva and G. Neiva Coelho, "The City's Architecture as Representation of Power: A Parallel between Brazil and Italy through the Plans of Golânia (1933) and Sabaudia (1933)," 15th International Planning History Society Conference, http://www.usp.br/fau/iphs/abstractsAndPapersFiles/Sessions/34/COELHO_ VALVA.PDF (last accessed 19 Nov. 2020).

3 P. Mainoldi, La conquista della Libia: Cronistoria dell'occupazione militare 1911-1930 (Bologna, 1930); N. Labanca, La guerra italiana per la Libia: 1911-1931 (Bologna, 2011).

4 R. Perger, Mussolini's Nation-Empire: Sovereignty and Settlement in Italy's Borderlands, 1922-1943 (Cambridge, UK, 2017), 243-53. 
space, neither fully a colony nor fully a metropolitan province. On one hand, it was a venue for targeting the local population with brutal attacks, segregation, and acculturation practices based on racialist rhetoric and ideals of white Italian supremacy. ${ }^{5}$ Yet it was also considered the "fourth shore" of Italy in the Mediterranean Sea, ${ }^{6}$ its legal and institutional status changed in early 1939 when it became a province of the Italian Kingdom, ${ }^{7}$ and it embodied a space dedicated to the creation of a pure and committed Fascist community from scratch (see image 1$)^{8}$

Libya is also crucial for a third reason: it was generally unsuitable for agriculture. A pioneering survey of Libyan soil had come out in 1912, when Italy proclaimed its sovereignty over the African country after the ItaloTurkish war. This brief and cautious study directly addressed soil properties with the intent to inform colonial agricultural development policy. Libyan soils' texture, structure, porosity, chemistry, and color all warned of a country almost entirely covered by desert sand. Available information about the frequency of rain or presence of underground water seemed anything but promising, and in terms of plant varieties and surface only limited valorization plans were deemed feasible. ${ }^{9}$ During this early Fascist period, in the eyes of Italian colonists Libya remained mostly arid desert. ${ }^{10}$

The dream of a green colony together with the transfer of a mass of white colonists from Italy took shape in the late $1920 \mathrm{~s}^{11}$ and was implemented in the 1930s. In 1932, the government established a sector-specific agency to lead the agricultural reclamation and demographic colonization of North Africa. In 1933 the first four settlement villages were established with the arrival of more than 2,200 colonists, and in 1938-1939 the Agency for the Colonization of Libya and the National Fascist Institute for Social Security

5 A. Del Boca, "I crimini del colonialismo fascista," in A. Del Boca, ed., Le guerre coloniali del fascismo (Roma-Bari, 1991), 232-55; A. Del Boca, Italiani, brava gente? (Vicenza, 2005), 107-27.

6 M. Moore and T. Philipps, "Forth Shore-Italy's Mass Colonisation of Libya," Journal of the Royal African Society 39, 155 (1940): 129-33.

7 Decree-Law, 9 Jan. 1939, no. 70; R. Vuoli, "La condizione giuridica del territorio libico," Il Foro Italiano 64, 4 (1939): 217-36.

8 "Statuto dell'ente per la colonizzazione della Cirenaica," 30 Nov. 1932; and Decree-Law 11, June 1932, no. 696, busta 1, Ente Colonizzazione Libia [hereafter ECL], Archivio Centrale dello Stato [hereafter ACS].

9 P. Bignami, Terra e acqua in Tripolitania e Cirenaica (Roma, 1912).

10 A. Fantoli, La siccitá in Libia (Firenze, 1935); H. Scaetta, Per un esperimento di bonifica dell'Agro Bengasino (Firenze, 1925), 4.

11 D. Atkinson, "Geographical Knowledge and Scientific Survey in the Construction of the Italian Libya," Modern Italy 8, 1 (2003): 2-29; S. Berthe, "Un impero di carte: 1'immagine della Libia nelle riviste turistiche 'Le Vie d'Italia' e 'Libia," Clio@Themis. Revue electronique d'histoire du droit 12 (2007): 1-14. For an overview of Italian colonialism under Fascist rule, see A. Del Boca, Gli italiani in Libia: Dal fascismo a Gheddafi, vol. 2 (Milano, 2011); and N. Labanca, Oltremare: Storia dell'espansione coloniale italiana (Bologna, 2002), 128-215. On the distinctive features of Italian colonialism, see H. M. Larebo, The Building of an Empire. Italian Land Policy and Practice in Ethiopia, 1935-1941 (Oxford, 1994), 65-67. 


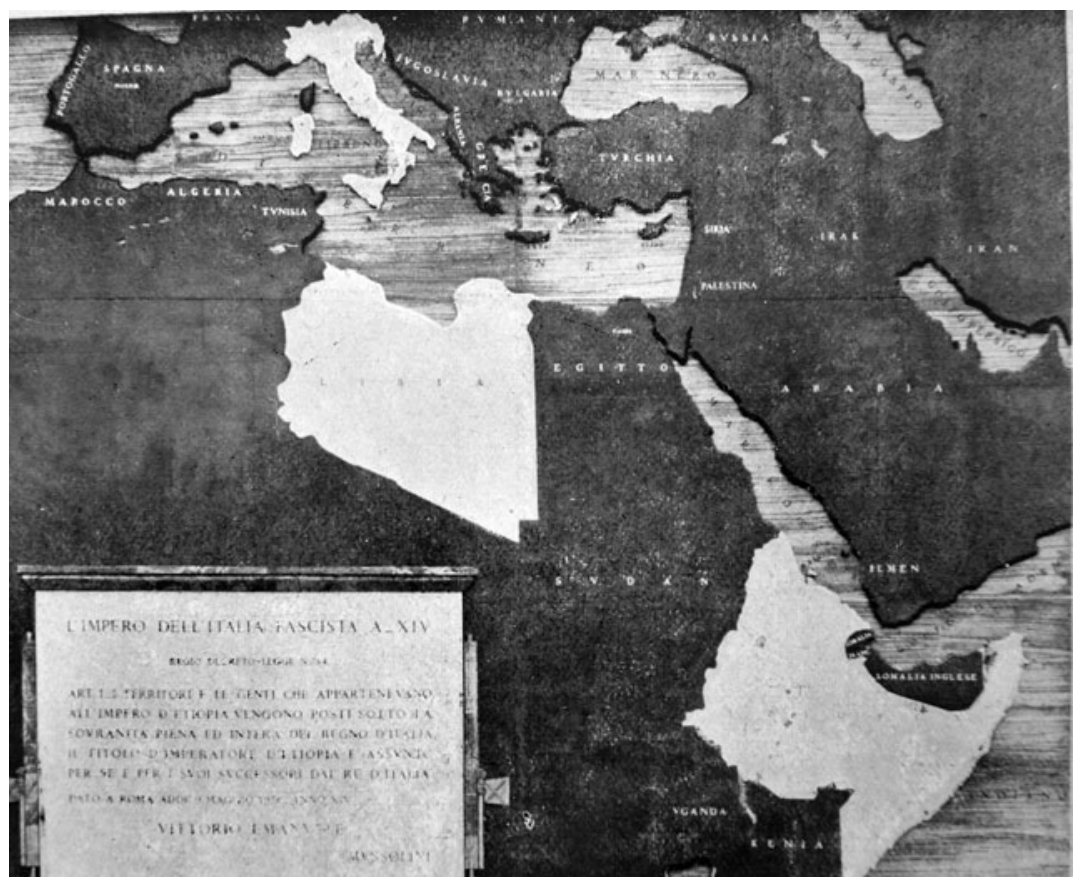

IMAGE 1: Marble map of the Italian Empire in 1936 on display, during the Fascit period, on one side of Via dell'Impero in Rome (the modern-day Via dei Fori Imperiali). Source: "La parola e l'esempio," Nazione e Impero. Rivista mensile di opere pubbliche, bonifica, colonizzazione Aprile-Maggio 4-5 (1937-XV): 4-8, 8, held in the Biblioteca Nazionale Centrale di Roma.

supported intensive programs of demographic colonization that allowed for a few dozen rural villages and the arrival of about thirty thousand white colonists. ${ }^{12}$ It was not a coincidence that this last injection of "farmerwarriors," the so-called "army of the thirty thousand," occurred just before Italy entered World War II. Libya was the Italian, or better, Axis outpost along the African coast. ${ }^{13}$ Despite propaganda and enormous financial resources, the Italian land transformation scheme covered at its peak an area of just 89,970 hectares out of Libya's total surface area of some $1,759,541$ square kilometers. ${ }^{14}$

12 F. Cresti, "The Early Years of the Agency for the Colonization of Cyrenaica (1932-1935)," in R. Ben-Ghiat and M. Fuller, eds., Italian Colonialism (New York, 2005), 73-82.

13 F. Cresti, Non desiderare la terra d'altri: La colonizzazione italiana in Libia (Roma, 2011), 179-205; R. Biasillo and C. M. da Silva, "Cultivating Arid Soils in Libya and Brazil during World War Two: The Two-Fold War between Colonial and Neo-Colonial Experiences," Global Environment 12, 1 (2019): 159-68.

14 Cresti, Non desiderare, 295-98. 
On the other side of the world, about two decades later, we find a comparable case of inner colonization and transcontinental exchange of soil expertise under authoritarian rule. In Brazil during the civil-military dictatorship (1964-1985), the neotropical savannah represented "one of the great frontiers of our time." 15 The way to the Green Revolution was paved by the expansion of agriculture, accelerating population growth, invigorated plantations and processing industries, increased national exports, and uneven international relations. ${ }^{16}$

A first decisive moment for the occupation of the inner regions came when the capital city was transferred from Rio de Janeiro to Brasília in 1960 and the interior was included in the national modernization project and the development of the great Brazilian West. ${ }^{17}$ In the early 1970s, a second transformative factor entered the picture: the international oil crisis and an internal diminution in food supplies contributed to yet another push for the transformation of the native Cerrado into "the breadbasket of the world."18 During that decade, natural scientists developed an interest in the great plateau of Central Brazil and its soil, vegetation, and production potential. ${ }^{19}$ Agrarian scientists tested and used fertilizers to neutralize the effects of soil acidity and soil-related constraints and financial credit and technical assistance programs helped to achieve high yields. ${ }^{20}$ The core and more fertile areas of Brazil's center-western savannah (the Cerrado biome), covering around one-fifth of the nation (about 2,045,000 square kilometers), changed dramatically. ${ }^{21}$

15 D. Hall, Land (Hoboken, 2013), 82-83. Despite that, grasslands, deserts, and semiarid regions have not received attention commensurate with their historical importance for the production of grains and livestock. See J. Soluri, C. Leal, and J. A. Padua, "Finding the 'Latin American' in Latin American Environmental History," in J. Soluri, C. Leal, and J. A. Pádua, eds., A Living Past: Environmental History of Modern Latin America (New York, 2018), 4.

16 A. Ribeiro Romeiro, "Alternative Developments in Brazil," in B. Glaeser, ed., The Green Revolution Revisited: Critique and Alternatives (London, 1987), 79-110. The more recent "civilmilitary dictatorship" terminology notes that the regime throughout its existence depended on civilian allies in business and government, as well as popular support: A. Pagliarini, "'De onde? Para onde?' The Continuity Question and the Debate over Brazil's 'Civil'-Military Dictatorship," Latin America Research Review 52, 5 (2017): 760-74.

17 The Manaus Free Trade Zone (MFTZ), which is regulated by Decree-Law no. 288/1967, was conceived as a free import and export trade area with special tax incentives. It was set up with the objective of creating an industrial, commercial, and agricultural center in the hinterland of the Amazon Region, which would be equipped with economic conditions that would enable the region to be occupied and developed.

18 Serviço Público Federal, Plano de Ação para Prevenção e Controle do Desmatamento e das Queimadas no Cerrado (Brasília, 2010), 11.

19 G. Eiten, "The Cerrado Vegetation of Brazil," Botanical Review 38, 2 (1972): 201-341; R. Goodland and R. Pollard, "The Brazilian Cerrado Vegetation: A Fertility Gradient," Journal of Ecology 61, 1 (1973): 219-24.

20 W. J. Goedert, "Management of the Cerrado Soils of Brazil: A Review," Journal of Soil Science 34, 3 (1983): 405-28.

21 C. C. Leite et al., "Historical Reconstruction of Land Use in the Brazilian Amazon (19401995)," Journal of Land Use Science 6, 1 (2011): 33-52; C. C. Mueller, "Regional 
Over about twenty years, in a context of rising international technological and scientific cooperation with the United States and emerging global markets, the processes of occupying and valorizing these vast areas, once considered "demographic vacuums," was achieved. The government's propagandistic claims that it would provide landless families with land and harness wastelands to boost national prosperity seemed to become reality. "22 "The conquest of the Cerrado" 23 was interwoven with the "conquest of the state" (see image 2). ${ }^{24}$

These two wheres and whens share more than overarching development schemes and types of political regime. Latin American and African red soils $^{25}$ became a means to build consensus and impose racial supremacies, functioned as a material place to resolve geopolitical tensions and seek international alliances, and served as a laboratory to test authoritarian scientific and technological capabilities.

However, the two situations differed widely in several important respects. The scale of farming modernization in the Cerrado dwarfed that in the Libyan settlements, which at their peak covered only 0.2 percent of the annexed territory. ${ }^{26}$ Further, modernity was performed differently in each in terms of symbols, discourses, and technoscientific and government apparatuses. In Libya, the project of societal transformation overshadowed the goal of

Development and Agricultural Expansion in Brazil's Legal Amazon: The Case of Mato Grosso," in W. Baer, ed., The Regional Impact of National Policies: The Case of Brazil (Cheltenham, 2012), 184-203; C. A. Klink, "Policy Intervention in the Cerrado Savannas of Brazil: Changes in Land-Use and Effects on Conservation," in A. G. Consorte-McCrea and E. Ferraz Santos, eds., Ecology and Conservation of the Maned Wolf: Multidisciplinary Perspectives (Boca Raton, 2013), ch. 21; C. A. Klink and A. G. Moreira, "Past and Current Human Occupation, and Land Use," in P. S. Olivera and R. J. Marquis, eds., The Cerrados of Brazil: Ecology and Natural History of a Neotropical Savanna (New York, 2002), 69-88.

22 A. Acker, Volkswagen in the Amazon: The Tragedy of Global Development in Modern Brazil (Cambridge, UK, 2017), 202.

${ }^{23}$ Embrapa, "Soils and Life-A Broad, Direct Relationship," https://www.embrapa.br/en/temasolos-brasileiros/solos-e-vida (last accessed 19 Nov. 2020); E. Paterniani and E. Malavolta, "The Conquest of the 'Cerrado' in Brazil: Triumph of Scientific Research," Interciencia 24, 3 (1999): $173-76$.

${ }^{24}$ R. A. Dreifuss, 1964: A conquista do Estado. Ação politica, poder e golpe de classe (Rio de Janeiro, 1981); G. V. Rezende, "Políticas Trabalhista, Fundiária e de Crédito Agrícola no Brasiluma Avaliação Crítica," Revista de Economia e Sociologia Rural 44, 1 (2006): 47-78; W. Shurtleff and A. Aoyagi, History of Soybeans and Soyfoods in South America (1884-2009) (Lafayette, 2009), 391.

${ }^{25}$ Red soil is a pedological classification for soils with low natural fertility. These soils' main limiting factors for good crop production are that they are frequently acidic, deficient in essential nutrients, and disaggregated. They also present low capillary water capacity. See V. C. Baligar et al., "Nature and Properties of Red Soils of the World," in M. J. Wilson, Z. He, and X. Yang, eds., The Red Soils of China (Dordrecht, 2004), 7-27.

${ }_{26}$ F. Micale, Agricoltura e decolonizzazione: prime considerazioni sulla geografia agraria della Libia (Palermo, 1979), 8. 


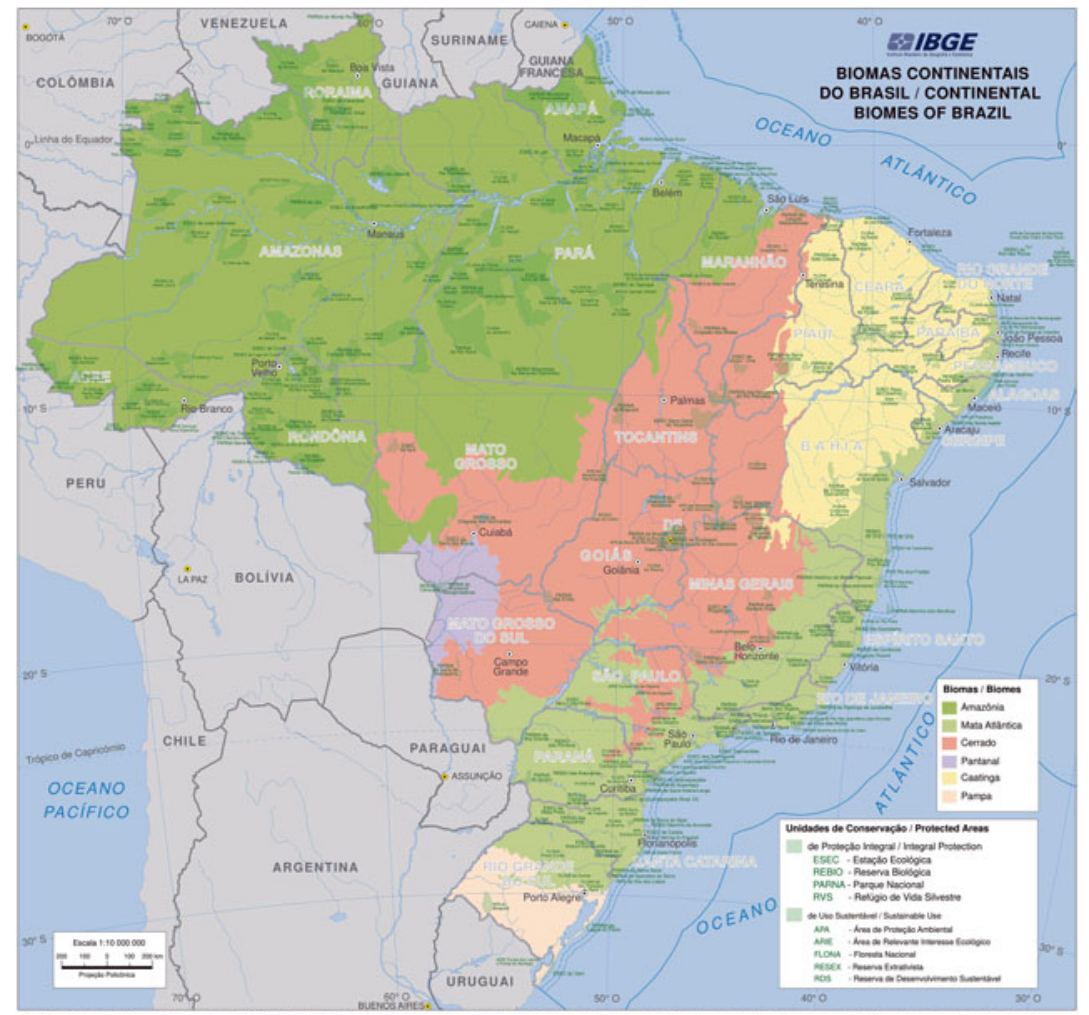

ImAGE 2: Biome Map of Brazil. Source: Instituto Brasileiro de Geografia e Estatística https:// portaldemapas.ibge.gov.br/portal.php\#homepage (last accessed 19 Nov. 2020).

economic profit, while in Brazil the latter gained momentum as the government began the conquest of the Cerrado. Scholars of Italian colonialism have stressed that Fascism succeeded more in creating a colonial mind-set and a long-lasting narrative of settler colonialism than in achieving any large-scale transformation that was profitable over the long-term. ${ }^{27}$ In Brazil, by contrast, the heartland regions of Goiás and Mato Grosso definitively became "agricultural states" that increased the country's role in the global marketplace. ${ }^{28}$

27 E. Ertola, “Terra Promessa': Migration and Settler Colonialism in Libya, 1911-1970,” Settler Colonial Studies 7, 3 (2017): 340-53, 345; S. M. Hom, Empire's Mobius Strip: Historical Echoes in Italy's Crisis of Migration and Detention (Ithaca, 2019), 1.

28 S. Spera, "Agricultural Intensification Can Preserve the Brazilian Cerrado: Applying Lessons from Mato Grosso and Goiás to Brazil's Last Agricultural Frontier," Tropical Conservation Science 10 (2017), https://doi.org/10.1177/1940082917720662. 
Via differences and similarities, then, these two soil systems crystallized complex dictatorial social organizations. The Libyan arid and semi-arid regions from 1922 to 1943 and the Brazilian savannah from 1964 to 1985 represent two different archetypes of agricultural-political relations that lend themselves to an in-depth, comparative exploration of the nexus between soils and societies, and particularly between soils as technical artifacts and authoritarian societies.

This article engages with the development of an environmental history of soils and seeks to contribute to the ongoing dialogue between environmental history and science and technology studies (STS). It is grounded in historiographical debates in English, Italian, and Portuguese, and draws from primary sources from the Rockefeller Archive Center in New York, the Archivio Centrale dello Stato in Rome, and several Brazilian and Italian library collections: Epagri Library in Santa Catarina, the EMATER collection of the Empresa Brasileira de Pesquisa Agropecuária (Embrapa) in Belo Horizonte, the Biblioteca da Presidência da República do Brasil, the Polo Bibliotecario Parlamentare Italiano, and the Istituto Agronomico per l'Oltremare in Florence.

\section{PREPARING THE GROUND}

The argument that the study of soils can unveil societal changes over time appeared in the early $1970 \mathrm{~s}^{29}$ and has been a feature of environmental history ever since. Environmental history officially emerged as a discipline in 1979, when Donald Worster published Dust Bowl: The Southern Plains in the 1930s, one of the most influential works about the nexus between economic and ecological failures in modern societies. As the title suggests, the main character in Worster's reconstruction is soil, but in the particular texture of dust. ${ }^{30}$ Despite its pioneering and founding role in the field, the history of soils has been perhaps the most neglected subject within environmental history. Over the last decade, John R. McNeill and Verena Winiwarter have provided insightful reflections on the interactions between soils and societies. Agricultural communities, as well as industrialized societies, and their social structures, economic prosperity, and political power are rooted in soil ecosystems, and they depend on their capacity to create and/or maintain a certain level of productivity. "Everywhere, long-term economic trajectories, the ebb and flow of political power, the waxing and waning of population, rested on the successful management of soil nutrients. For want of nitrogen, many a kingdom was lost."31

29 A. Ruellan, "The History of Soils: Some Problems of Definition and Interpretation," in D. H. Yaalon, ed., Paleopedology: Origin, Nature and Dating of Paleosols (Jerusalem, 1971), 3-13.

30 D. Worster, Dust Bowl: The Southern Plains in the 1930s (Oxford, 2004), 12-13.

31 J. R. McNeill and V. Winiwarter, Soils and Societies: Perspective from Environmental History (Isle of Harris, 2006), 2-4. 
The search for how to successfully manage soils recurs in many twentiethcentury dictatorial regimes and to this ecological pursuit dictatorships have tied socioeconomic systems of oppression and modernization. One of the most explored attempts to reorganize society through investments in rural infrastructure, increasing soil productivity, and establishing rural settlements in marginal areas unsuitable for agriculture was the "Blood and Soil" ideology elaborated by R. Walther Darré, Minister of Agriculture under the Nazis from 1933 to $1942 .{ }^{32}$ A comparable "ideology of the land" materialized in three Portuguese initiatives launched by the fascist New State: the Wheat Campaign (1929), the Irrigation Plan (1935), and the Afforestation Plan (1938). Tiago Saraiva noted how, more generally, this ideology expresses the reactionary element at the core of any fascist national modernism; "projects intended to make the national soil feed the national body" were the backbone of what he defines as "the paradox of reactionary modernism." 33 In socialist counties, too, were found peasants tied to their land, state-owned economies, agricultural mechanization, and considerable progress in increasing the agricultural output. ${ }^{34}$ The Soviet $1920 \mathrm{~s}$ New Economic Policy forged a class alliance between the Party and the peasantry, allowed Lenin to consolidate the communists' hold on the country, and facilitated a rebound in economic production. ${ }^{35}$ Since only a small portion of the USSR had the combination of soil, precipitation, and temperature required for low-cost and non-irrigated agriculture, in 1948 Stalin announced a state-centered program to reverse ecological degradation, a grandiose plan to construct 5.7 million hectares of forest in the Russian south. ${ }^{36}$ Khrushchev's agrarian policies were instead directed toward the vast prairies of the East, with the launch of the "virgin land program." 37

While soils anchored socio-environmental policies, they were turned literally into testing grounds, which forged a second essential bond between

32 A. Branwell, Blood and Soil: Richard Walther Darré and Hitler's 'Green Party' (Abbotsbrook, 1985); D. Blackbourn, The Conquest of Nature: Water, Landscape, and the Making of Modern Germany (New York, 2007), 251-309; P. Staudenmaier, "Organic Farming in Nazi Germany: The Politics of Biodynamic Agriculture, 1933-1945," Environmental History 18, 2 (2013): 383-411.

33 T. Saraiva, "Fascist Modernist Landscapes: Wheat, Dams, Forests, and the Making of the Portuguese New State," Environmental History 21, 1 (2016): 54-72.

34 M. Ellman, "Agricultural Productivity under Socialism," World Development 9, 9/10 (1981): 979-89; S. Engel-Di Mauro, Ecology, Soils, and the Left: An Ecosocial Approach (London, 2014).

35 S. K. Wegren, Agriculture and the State in Soviet and Post-Soviet Russia (Pittsburgh 1998), 1.

36 S. Brain, "The Great Stalin Plan for the Transformation of Nature," Environmental History 15, 4 (2010): 670-700.

37 M. McCauley, Khrushchev and the Development of Soviet Agriculture: The Virgin Land Programme 1953-1964 (London, 1976); N. M. Dronin, and E. G. Bellinger, "The Virgin Lands Campaign (1955-1964)," in N. M. Dronin and E. G. Bellinger, eds., Climate Dependence and Food Problems in Russia, 1900-1990: The Interaction of Climate and Agricultural Policy and Their Effect on Food Problems (New York, 2005), 171-218. 
economic policies and scientists. Science in Spain during Francoism (19391975) supported and developed together with autarkic plans, ${ }^{38}$ and studies of Spanish agriculture have documented the coproduction of corporatism and scientific innovations. ${ }^{39}$ Regarding the left-wing side of the political spectrum, Sigrid Schmalzer has reconstructed the emergence of the Chinese "scientific agriculture" during the Mao era between 1960 and 1980 and its entanglements with the Cultural Revolution, different social groups, and China's economic network. Through the promotion of new machines, seeds, and chemicals, the Communist Party promoted both the green and red revolutions. ${ }^{40}$

This second bond brings us to a subsequent grounding aspect of environmental history as a discipline: the opportunity to bridge the gap between sciences and humanities, ${ }^{41}$ or more precisely, to historicize science and technology. The conceptualization of soils as a materialization of political propositions and technological manipulation positions this research at the overlap between environmental history and STS, thus helping to foster the burgeoning theoretical dialogue between these fields. The recent volume New Natures: Joining Environmental History with Science and Technology Studies, edited by Dolly Jørgensen, Finn Arne Jørgensen, and Sarah B. Pritchard, highlighted how conceptual STS tools can unpack the construction of knowledge and the development of technology as social processes, helping us to deepen and transform our understanding of past human-natural interactions and thereby gain a richer understanding of how historical actors have constructed, perceived, contested, and reshaped the environment. ${ }^{42}$

Both of the "new soils" examined here represents what Pritchard calls an "envirotechnical system," a regime defined, justified, and maintained by and across "institutions, people, ideologies, technologies, and landscapes."43 Each such system expresses a specific combination of nature, culture, power,

${ }^{38}$ N. Herran and X. Roqué, “An Autarkic Science: Physics, Culture, and Power in Franco's Spain," Historical Studies in the Natural Sciences 43, 2 (2013): 202-35.

39 L. Camprubí, "One Grain, One Nation: Rice Genetics and the Corporate State in Early Francoist Spain (1939-1952)," Historical Studies in the Natural Sciences 40, 4 (2010): 499-531.

40 S. Schmalzer, Red Revolution, Green Revolution: Scientific Farming in Socialist China (Chicago, 2016).

41 D. Worster, "The Two Cultures Revisited: Environmental History and the Environmental Sciences," Environment and History 2, 1 (1996): 3-14.

42 S. B. Pritchard, "Joining Environmental History with Science and Technology Studies: Promises, Challenges, and Contributions," in D. Jørgensen, F. A. Jørgensen, and S. B. Pritchard, eds., New Natures: Joining Environmental History with Science and Technology Studies (Pittsburgh, 2013), 1-17.

43 S. B. Pritchard, Confluence: The Nature of Technology and the Remaking of the Rhône (London, 2011), 17-23; S. B. Pritchard, "Towards an Environmental History of Technology," in A. C. Isenberg, ed., The Oxford Handbook of Environmental History (Oxford, 2017), 244-45; S. B. Pritchard, "An Envirotechnical Disaster: Nature, Technology, and Politics at Fukushima," Environmental History 17, 2 (2012): 219-43, 219-21. 
and science and technology, and via these "technopolitical" designs of soil fertilization we can read soils' and societies' co-productive relationship. ${ }^{44}$ The soil appears here as organically tied to the body of the nationengineering soils means engineering societies. Material manipulations of soils also make the ideological coherence of regimes possible since soil becomes a way of constituting the organic body of the nation, not only by feeding it but also through the work of experts and the labors of peasants and the common ground that elites and masses are given to mobilize and serve authoritarianisms. Authoritarian soils synthesize corporatism and economic dirigisme, mobility schemes and forced displacement, social and political consensus, geopolitical power shifts, scientific and technological advances, racialized social relationships, and radical transformations of natural environments. Although the two cases we present here exhibit differences, soil was crucial to both, and both highlight how soil is malleable and can be materially mobilized for multiple projects.

Science- and technology-based state schemes are indicators of "the culture and politics of modernity." 45 We share Lars Denicke's definition of modernization as "the attempt of a nation ... to upgrade its infrastructure to achieve a status that would put it on equal terms with the great powers." In order to become modern, Italy adopted a pre-World War II strategy, colonialism, whereas Brazil adopted the central concept of Cold War technopolitics of modernization, globalism. ${ }^{46}$

What follows will lay out how Libyan deserts and Brazilian savannahs, along with their communities, were transformed into authoritarian soils. Echoing Tiago Saraiva, we will look at soil as a "thick thing" able to encompass multiple meanings-scientific, cultural, social, political, and economic - in the production of historical accounts. In doing so, we do not simply consider Italian fascism and Brazilian civil-military dictatorship as space-time stages in which certain soil transformations took place; we focus on ways in which soil-related discourses and techniques "became constitutive" of totalitarian states and embodied authoritarianisms. ${ }^{47}$

44 G. Hecht, "Introduction," in G. Hecht, ed., Entangled Geographies: Empire and Technopolitics in the Global Cold War (Cambridge, Mass.), 3; S. Jasanoff, "In a Constitutional Moment: Science and Social Order at the Millennium," in B. Joerges and H. Nowotny, eds., Social Studies of Science and Technology: Looking Back, Ahead (Dordrecht 2003), 155-80; S. Jasanoff, "The Idiom of Co-Production," in S. Jasanoff, ed., States of Knowledge: The CoProduction of Science and Social Order (New York, 2016), 1-12.

45 S. Jasanoff, "Idiom of Co-Production," 1.

46 L. Denicke, "Fifty Years' Progress in Five: Brasilia-Modernization, Globalism, and the Geopolitics of Flight," in G. Hecht, ed., Entangled Geographies: Empire and Technopolitics in the Global Cold War (Cambridge, Mass.), 185-86.

47 T. Saraiva, Fascist Pigs: Technoscientific Organisms and the History of Fascism (Cambridge, Mass. 2016), 3, 237-38. For the materialization and co-constitution of the material and cultural dimensions of authoritarian regimes in urban landscapes, see E. Gentile, Fascismo di pietra 
In the making of Italian Libya, the transformation of Libyan desert represented an upgrade of cultural, ecological, and social infrastructures that allowed Italian Fascism to complete its self-identification with a modern regime via colonization. ${ }^{48}$ Studying Brazil's developmentalist state draws one into a daunting maze of acronyms of state, para-state, foreign, and private organizations and programs built upon economic crisis, Weberian bureaucracy, and collaborations between business, scientific expertise, and authoritarian institutions. $^{49}$

AN ECOLOGICAL JOURNEY INTO FASCIST MODERNITY: BLACK SHIRTS IN A VERDANT LIBYA (1922-1943)

In 1936, the Fascist Institute of Agricultural Techniques and Propaganda (Istituto Fascista di Tecnica e Propaganda Agraria) and the National Fascist Union of Agrarian Technicians (Sindacato Nazionale Fascista dei Tecnici Agrari) organized their first joint congress to appraise Italian agricultural production and discuss methods to increase it. Soil was, of course, one of the main topics of conversation. In a speech there, parliamentarian and agrarian science expert Emanuele De Cillis addressed the issues grounding a Fascist definition of soil — or a definition of Fascist soil — as a "dynamic" compound and introduced the "organic" theory of fertility. "The ground is a medium for uncountable activities, incessant transformations, which affect the life, growth, and product of a plant ... thus the fertility is that whole array of actions that the earth itself exerts over vegetables." In detailing his theories, he drew a comparison with the pre-Fascist period. Soil fertility during the Italian liberal regime (1861-1922) had been an isolated and confined objective achievable only through fertilization, but during the 1920 s and 1930s technicians had reinterpreted it as a complex restorative interaction between organic remains, clay, rock particles, plants, chemical and natural substances, and living organisms. To increase production-the measurement of fertility - soil should be the perfect hygienic home for its flora and any noxious or offensive elements should be removed. On the other hand, roots should attach to the ground, breathe underground, and convey water and

(Roma-Bari, 2007); H. Hökerberg, ed., Architecture as Propaganda in Twentieth-Century Totalitarian Regimes: History and Heritage (Firenze, 2018).

${ }^{4}$ On fascism and modernity, see R. Ben-Ghiat, Fascist Modernities: Italy, 1922-1945 (Berkeley, 2001); R. Griffin, Modernism and Fascism: The Sense of a Beginning under Mussolini and Hitler (London, 2007); and R. Griffin, "Modernity, Modernism, and Fascism: A 'Mazeway Resynthesis," Modernism/Modernity 15 (2008): 9-24.

49 P. Evans, Embedded Autonomy: States and Industrial Transformation (Princeton, 1995); A. Kohli, State-Directed Development: Political Power and Industrialization in the Global Periphery (New York, 2004); B. R. Schneider, "The Developmental State in Brazil: Comparative and Historical Perspectives," Brazilian Journal of Political Economy 35, 1 (2015): 114-32. 
nourishment to the rest of the plant. In this approach, the creation or restoration of fertility relied upon harmonizing several procedures: rendering the upper layer of earth sufficiently thick; improving soil drainage; loosening hard soils to allow better water and air penetration; selecting the most appropriate crops with the greatest tolerance to specific environments and growing conditions; and fertilizing efficiently to maximize product yields. The application of fertilizers was merely a single and final step within this complex process. ${ }^{50}$

Two other speeches from the published records of the day-long 1936 congress refined this definition and plainly described Fascist soil as a "techno-political" category in which the political sphere had to provide frames and objectives, while the technological sphere had to determine the feasibility of political plans. ${ }^{51}$ Livio Gaetani, the secretary of the National Fascist Union of Agrarian Technicians, stated that agricultural technopolicies sprang from either "a technologized politics" or "a policy-oriented technology." ${ }^{52}$ Giuseppe Tassinari, then undersecretary of the Agriculture and Forest Ministry, asked Italian scientists to abandon any form of skepticism, "sharpen their blades," and improve soil productivity in the belief that only self-sufficient economic system would ensure the nation's sovereignty. ${ }^{53}$ This linkage between self-sufficiency, colonialism, and agriculture found in Libya a fertile terrain for implementation: autarky was both a premise and consequence of Italian expansionism. ${ }^{54}$ Libya, like other Italian regions where adverse climatic conditions made cultivation difficult,

50 E. De Cillis, "La concezione integrale della fertilità nella tecnica agraria, in Istituto Fascista di Tecnica Agraria, Sindacato Nazionale Fascista dei Tecnici Agricoli," in Atti del primo convegno nazionale per l'incremento delle produzioni agricole (Roma, 5 dicembre 1936 XV) (Roma, 1937), vol. XV, 113-15.

51 R. Sottilaro, "Scienza e autarchia," L'industria Nazionale 2-3 (1938): 47-48. The relationship between technological systems, political power, and social constructions is an important theme in the field of STS. See, among many others, T. P. Hughes, "The Evolution of Large Technological Systems, in W. E. Bijker, T. P. Hughes, and T. Pinch, eds., The Social Construction of Technological Systems: New Directions in the Sociology and History of Technology (Cambridge, Mass., 1987), 51-82; D. MacKenzie, Inventing Accuracy: A Historical Sociology of Nuclear Missile Guidance (Cambridge, Mass., 1990). Historians have noted that the ability of the Italian state to involve experts in policy-making processes characterized governments embracing highly "finalistic-ideological purposes," namely Mussolini's government: C. Fumian, "Modernizzazione, tecnocrazia, ruralismo: Arrigo Serpieri," Italia contemporanea 137 (1979): 3-33, 5; L. D’Antone, “Tecnici e progetti: Il governo del territorio," Meridiana. Rivista di storia e scienze sociali 10 (1990): 125-40, 126-28.

52 L. Gaetani, "I nuovi imperativi dell'azienda agraria," in Istituto Fascista di Tecnica Agraria, Sindacato Nazionale Fascista dei Tecnici Agricoli, in Atti del primo convegno nazionale per l'incremento delle produzioni agricole (Roma, 5 dicembre 1936 XV) (Roma, 1937), 82.

53 E. Tassinari, "Discorso inaugurale," in Istituto Fascista di Tecnica Agraria, Sindacato Nazionale Fascista dei Tecnici Agricoli, in Atti del primo convegno nazionale per l'incremento delle produzioni agricole (Roma, 5 dicembre 1936 XV) (Roma, 1937), 3-11.

54 P. Morgan, Italian Fascism, 1915-1845 (New York, 2004), 76-176; E. Gentile, Il fascismo in tre capitoli (Roma-Bari, 2004), 45-48. 
became a target of research efforts. ${ }^{55}$ Particularly after 1936, the Fascists multiplied the resources that liberal governments had devoted to agricultural initiatives and experimentation many times over, and their main tools were plant breeding and hybridization, chemical fertilizers, mechanization, and new research institutes. ${ }^{56}$ These agricultural techno-policies constructed Libyan soon-to-be-Fascist soil and were elaborated together with it.

Scientists were assigned to be the engines of Fascist land reclamation, "to wake up sleepy, but not extinguished energies of the land and reestablish its ancient productivity." $" 57$ In Libya specifically, the past they had to bring back to life was not the socioeconomic backwardness of the early twentiethcentury, but rather the grandeur of Roman imperial civilization, whose traces were identified in the remains of small verdant oases and water supply systems along the coast. ${ }^{58}$ From 1922 until 1940, these natural oases were progressively expanded into small experimental lots, private latifundia-type estates, state land grants, and finally, rural villages managed by state or parastate colonization companies employing a growing number of Italian migrants and indigenous workers. ${ }^{59}$ Each agricultural enterprise proceeded, or was supposed to proceed, following certain steps. A technical commission was appointed to decide the general types of cropping and therefore the size and character of farms and their buildings; how many years would be necessary to establish the farms (the maximum being five); the relation between the irrigated and dry cultures; how many families would be introduced into each zone; and the price a colonist would pay for his farm once it reached a specified level of soil fertility and productivity. ${ }^{60}$

The preparatory phase consisted of two stages: first came deforestation, eradication of all indigenous plants and insects (especially locusts), and tillage. In the second stage, irrigation was ensured by drilling wells, and

55 G. Tommasi, "Nuova dottrina integrale della concimazione," in Istituto Fascista di Tecnica Agraria, Sindacato Nazionale Fascista dei Tecnici Agricoli, in Atti del primo convegno nazionale per l'incremento delle produzioni agricole (Roma, 5 dicembre 1936 XV) (Roma, 1937), 130-33.

56 "Le colture sperimentali autunno-vernine eseguite dall'Ufficio Agrario Provinciale di Tripoli nel 1936-37," Agricoltura Libica 7, 2 (1938 XV): 41-65, 42-49; G. Vivoli, "Della recente sperimentazione agraria e zootecnica in Libia," Agricoltura Libica 7, 10 (1938 XVI): 437-46; V. Di Cairano, "Norme per la coltivazione del grano nella Libia Occidentale," Agricoltura Libica 7, 11 (1938 XVII): 493-99, 494; E. Bernardi, "La sperimentazione tra fascismo e dopoguerra," Dimensioni e problemi della ricerca storica 1 (2013): 209-23, 211; S. Salvatici, "L'Istituto Nazionale di Economia Agraria: l'istituzione, gli uomini, le ricerche," Le Carte e la Storia: Rivista di Storia delle Istituzioni 1 (1999): 204-17.

57 G. Narducci, Storia della Colonizzazione della Cirenaica (Milano and Roma), 89-92.

58 M. Palmeri, "The Time of the Myth: Situating Representations of the Roman Empire within Italian Colonialism, 1911-1940," Global Histories 3, 2 (2017): 103-20.

59 G. L. Fowler, "Decolonization of Rural Libya," Annals of the Association of American Geographers 63, 4 (1973): 490-506, 491-96.

${ }^{60}$ E. J. Russell, "Agricultural Colonization in the Pontine Marshes and Libya," Geographical Journal 94, 4 (1939): 273-89, 282-83. 
violent desert winds and encroaching sands were mitigated by planting blocks of eucalyptus along fields edges. Also, the soil was replenished with organic components through the introduction of livestock and the cultivation of nitrogen-fixing plants. $^{61}$ The actual demographic and agricultural colonization, which started in 1932-1935, focused on plant adaptation and an articulation of the last steps into three sub-phases: (1) introduction of olive and almond trees and vineyards; (2) introduction of working animals, tools, and machineries; and (3) realization of intensively cultivated and densely populated modern farms producing cereals - mostly wheat but also oat and barley - and breeding cattle and ovine. ${ }^{62}$

There were other ways in which the southward expansion of the Italian colonial enterprise in Libya depended on science and technology, notably in the search for water and methods to regenerate fertility. The Italian Government constructed two major aqueducts: one in Tripolitania was 80 kilometers long and delivered 24,000 cubic meters of water daily, and a second in Cyrenaica was 150 kilometers long and delivered 96,000 cubic meters. The government also constructed many artesian wells near Italian settlements. ${ }^{63}$ Experiments were conducted to find the best way to replenish poor Libyan soils with macronutrients (nitrogen, phosphorus, potassium, and sulfur) and suggest successful and organic methods to farmers. The use of chemical fertilizers faced two main impediments: despite the regime's production efforts, Italy only met 60 percent of its national demand and, in combination with chronic lack of precipitation and irrigation, chemical fertilizers could harm plants. The main source of nutrients remained animal manure, supplemented by growing broad beans and alfalfa, deep plowing, and burning after harvests. ${ }^{64}$

Despite agrarian science and Fascist faith, only modest villages and farms were established. Yet because of the state's ambition to remodel the African space, these were a core element of the regime's propaganda. ${ }^{65}$ "A strong, drilling, and constant propaganda" was seen as key to boosting soil fertility and meeting the need to showcase the regime's achievements so as to motivate individuals and raise productivity levels. ${ }^{66}$ One particular type of

61 G. Leone, Saggio di bonifica agraria in Tripolitania: Azienda Leone-Ortu (Firenze, 1930), 5 8; "Relazione del Presidente dell'Ente Colonizzazione Libia," 4 gennaio 1936, Fascicolo 2, busta 2 , ECL, ACS; G. Palloni, "Colonizzazione demografica intensiva, Agricoltura Libica” 8, 1 (1939 XVII): $1-14,2-4$.

62 ECL, n.d. Compartimento della Cirenaica [grafico], fascicolo 2, busta 2, ECL, ACS.

63 Russell, "Agricultural Colonization," 282-83.

64 The monthly bulletin of the Central Royal Office for Agrarian Services in Libya, Agricoltura Libica, dedicated a section to practical suggestions and scientific reports on the most effective cultivation methods. From 1937 onward, most of these practical notes concerned soil treatments.

65 G. Baglione, "Relazione sull'andamento dei campi dimostrativi dell'annata agraria 1937-38 in provincia di Derna,” Agricultura Libica 7, 4 (1939 XVII): 148-55, 148.

${ }^{66}$ G. Medici, "Politica ed economia agraria nel momento presente," in Istituto Fascista di Tecnica Agraria, Sindacato Nazionale Fascista dei Tecnici Agricoli, Atti del primo convegno 
propaganda, filmmaking, became part and parcel of the spiritual and material redemption of nature, and films presented step by step the major "struggle to turn sterile nature ... into fertile landscapes." Newsreels and documentaries promoted landscape transformation as a mission, "a heroic quest" to produce proper Fascist and fertile landscapes and communities. To reach a wider public arena, they were distributed for compulsory general viewing. Every stage of the reclamation process was recorded and reworked on film to produce a distinct vision of Fascist soil. ${ }^{67}$ Fascist newsreels and films both made modernity visible and modernized visual propaganda.

Just how topical, engaging, and relevant the cinematographic celebration of penetrating new-found land to revivify wasted soil was is exemplified by the cinematic representation of Fertilia - literally "the fertile place" - one of the regime's new towns in Sardinia. Gino Rovesti's 1936 documentary Fertilia di Sardegna fulfilled the overarching aim of portraying the national project of modernization while detailing the reclamation work. The place is initially addressed as having been "sterile," "without any sign of life," and "the last of infertile areas," where "men had been denied the possibilities for their livelihoods," but as then having become "workable" and "thick with all the fruits of Italy" after the soil was broken up and rid of palm groves and parasitical vegetation, irrigation canals were created, and infrastructure and houses were built. ${ }^{68}$ Tripolitania and Cyrenaica were the imperial fertilias, and propagandistic movies and videos translated Mussolini's claims and dreams into sounds and images and demonstrated that they were achievable and real. Cinematographic Libya was an immense and expanding panorama of "working landscapes" animated by powerful water irrigation systems, modern combine harvesters, white pioneer farmers, and subjugated indigenous people. ${ }^{69}$ Reclaimed land and transformed soils played the main characters in this aesthetic modernity, ${ }^{70}$

nazionale per l'incremento delle produzioni agricole (Roma, 5 dicembre 1936 XV) (Roma, 1937), $35-45,42$.

67 F. Caprotti and M. Kaika, "Producing the Ideal Fascist Landscape: Nature, Materiality and the Cinematic Representation of Land Reclamation in the Pontine Marshes," Social and Cultural Geography 9, 6 (2008): 613-34, 613-14, 624.

68 S. Carta, "Sardinia in Fascist Documentary Films (1922-1945)," Journal of Italian Cinema and Media Studies 1, 2 (2013): 171-87, 171-72, 181-83.

69 "Immagini di Tripoli e metodi agricoli utilizzati nella colonia italiana, 1928-1933," Repertorio INCOM, cod. fil. RI 0001031, Archivio Istituto Luce [hereafter AIL]; "Cirenaica," 1930, cod. fil. MO13505, AIL; "Lavori agricoli in Tripolitania," Gennaio 1931, Giornale Luce A/A0706, cod. fil. A070603, AIL; "La valorizzazione agricola,” 27 July 1938, Giornale Luce B/ B134707, AIL; A. Ricotti, "Immagini della Cirenaica e delle nuove coltivazioni di grano," 24 Aug. 1938, Giornale Luce B/B136207, AIL.

R. J. Golsan, ed., Fascism, Aesthetics and Culture (London, 1992); S. Falasca-Zamponi, Fascist Spectacle: The Aesthetics of Power in Mussolini's Italy (Berkeley, 1997). 
and the African region was portrayed as now possessing "Italian physiognomy and soul.",71

Italian agricultural modernization endeavored to achieve political consensus and reinforce uneven socioeconomic power relations. ${ }^{72}$ In addition to the reclamation and transformation of landscapes, the Fascists sought to reclaim of the human and the cultural. ${ }^{73}$ Rural migrant workers and indigenous peoples were made part in this experiment. The formal agreement between the Colonization Agency and each colonizer made clear to farmers that they were part of a grand colonial, demographic, and developmental scheme, and because of that they were a manifestation of the interests of the supreme and all-inclusive state. ${ }^{74}$ Regenerating nature implied the regeneration of people, and, as stated in one administrative file concerning the foundation of rural villages in Tripolitania and Cyrenaica: "Man and land were expected to undergo a parallel development"- to grow together. ${ }^{75}$ Colonization itself was conceived as an opportunity to give humans back to the land, and through them, to make the soil fertile and able to nurture Fascist vegetation and Fascist communities. ${ }^{76}$ In such an integral totalitarian society, just as no room was left for undesirable plants such as infected trees and unacclimated specimens, ${ }^{77}$ there was no place for unhealthy, undisciplined, or morally questionable Italians with limited reproductive and working capacity. ${ }^{78} \mathrm{New}$ Italian colonists, made stronger by war and the colonization enterprise, would show the world that they represented the new type of Italian created by the Fascist regime: sober, warrior-like, vital, and prolific. ${ }^{79}$ Indigenous tribes and communities were either expunged from coastal regions occupied by Italians, acculturated, subjugated in state reclamation projects and private plantation schemes, or, if

71 "La seconda migrazione sulla quarta sponda si é compiuta con lo sbarco a Tripoli," 5 Nov. 1939, Giornale Luce B/B161805, AIL.

72 L. D'Antone, "La modernizzazione dell'agricoltura italiana negli anni Trenta," Studi Storici 22, 3 (1981): 603-29, 610.

73 Ben-Ghiat, Fascist Modernities, 4; M. Armiero, "Introduction: Fascism and Nature," Modern Italy 19, 3 (2014): 241-45, 241-42.

74 "Contratto tipo di colonizzazione con promessa di cessione della attività," in Atti e Documenti, fascicolo 15, busta 6, ECL, ACS.

75 "Relazione del 1937," fascicolo 2, busta 2, ECL, ACS.

76 The co-development of humans, mainly men, and soil is a recurring element in the file by the ECL: "Notizie circa l'attività svolta in Cirenaica dall'ECL," 4-5; "Stato di fatto dell'ECL al febbraio 1937-XV E. F. Tripolitania," 3-4, fascicolo 2, busta 2; ECL, ACS; "Situazione Cirenaica," 28 Feb. 1942, fascicolo 7; busta 5, ECL, ACS; "Contratto colonico per la zona di Tarhuna," fascicolo 15, busta 6, ECL, ACS.

77 "Fornitura 50.000 piante d'ulivo-Ditta Fratelli Navarra Abramo (1939-40)," fascicolo 68, busta 19, Carte della Colonizzazione, Fondo Libia, Archivio Storico INPS.

78 "Regio Decreto Legge 11 giugno 1932-X n. 696," busta 1, ECL, ACS; “Gli annali dell'Africa Italiana," L'Italia Coloniale 9 (1938): 136.

${ }^{79}$ G. L. Podesta, 'Colonists and 'Demographic' Colonists: Family and Society in Italian Africa," Annales de démographie historique 122, 2 (2011): 205-31. 
they rebelled, eliminated. ${ }^{80}$ Libyan nature and its inhabitants would now be solely Fascist, participating in and contributing to the "totalitarian modernity," ${ }^{, 11}$ that newly achieved, corporative society in which all interests and social and racial groups assimilated themselves according to the will of a supreme state and its regulations. ${ }^{82}$

De Cillis' definition of Fascist soil emerged in 1936 amidst the consolidation of Fascism as a totalitarian state according to Mussolini's formulation, "Everything in the State, nothing outside the State, nothing against the State." Relying on analyses of major constitutional law experts of the period, we can argue that by simply replacing an ecological lexicon with socio-political terms the initial definition of soil fit the Fascist regime as it was organized in 1936. At that time, the state could indeed be described as "a medium for uncountable activities, incessant transformations, which affect the life, growth, and product of a society, ... thus the fecundity is that whole array of actions that the State itself exerts over the society" (see image 3 ). ${ }^{83}$

Paradoxically, scientists and technicians created a modern landscape to support a society that was anti-modern, frugal, and rural. They were asked to be innovative to create an alternative to modernity or, as Tiago Saiva has put it, to establish a Fascist "alternative modernity." ${ }^{, 4}$ Libyan colonization marked an important milestone not only in the fascist history of environmental restoration but also in the history of Italian Fascism tout court. It responded to and was triggered by the intrinsic tendency of the regime to nationalize peripheral landscapes and communities, a top-down propensity that historian Salvatore Lupo recognizes as another essential feature of fascism leading toward an "authoritarian modernization." ${ }^{85}$ Fascist

${ }^{80}$ M. Moore and T. Philipps, "Fourth Shore-Italy's Mass Colonisation of Libya," Journal of the Royal African Society 39, 155 (1940): 129-33, 132-33; G. Bassi, Sudditi di Libia (Milano, 2018).

81 Gentile, Il fascismo, vi-vii.

82 A. Gagliardi, Il corporativismo fascista (Roma-Bari, 2010); G. Melis, La macchina imperfetta: Immagine e realtá dello stato fascista (Bologna, 2018), 412-48.

83 Sergio Panunzio, an expert in revolutionary syndicalism, in his "General theory of the Fascist state," highlighted as essential characteristics of the Fascist regime after 1936 both its dynamism, as it developed out of a revolution, and its relationality, as it synthesized all the interests of the nation. Teoria generale dello stato fascista: Appunti di lezioni (Padova, 1937), 49-51. Alfredo Rocco, jurist and Minister of Justice from 1925 to 1932, stressed the beneficial effects of a strong state government on the economic and moral living conditions of the population, in $L a$ trasformazione dello Stato: Dallo Stato liberale allo Stato fascista (Roma, 1927).

84 M. Pasetti, "Un 'colonialismo corporativo'? L'imperialismo fascista tra progetti e realtà," Storicamente 12, 38 (2016): 1-30; G. Mondaini, "Colonie e corporativismo," in R. Istituto Superiore di Scienze Sociali e Politiche "Cesare Alfieri," Atti del secondo congresso di studi coloniali, Napoli 1-5 ottobre 1934 XII, vol. V, IV Sezione: Giuridica (Firenze, 1936), 53-82; Saraiva, Fascist Pigs, 3, 9-13.

${ }^{85}$ S. Lupo, Il fascism: La politica di un regime autoritario (Roma, 2005), 341-58. 


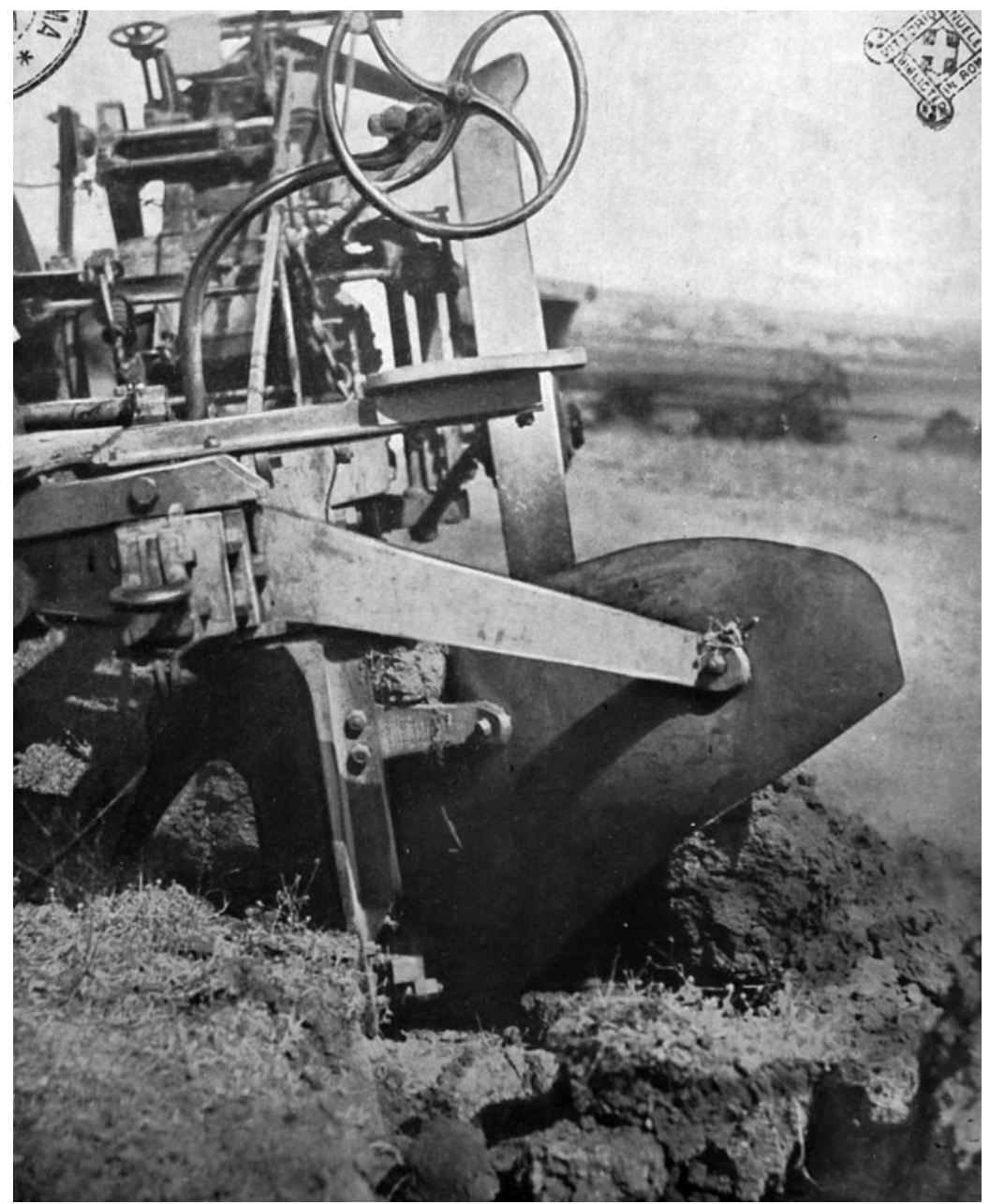

Image 3: "The Soil's Redemption," Nazione e Impero. Rivista mensile di opere pubbliche, bonifica, colonizzazione 6 (1937-XV), cover page, held in the Biblioteca Nazionale Centrale di Roma.

redefinition of national topographies ${ }^{86}$ informed internal colonization projects and migration flows and, particularly during the 1930s, evolved along with the colonial agenda. According to historian Alberto De Bernardi, in that decade land redemption and civilization efforts in remote areas of Italy and colonial

86 This expression recalls N. Santiáňez, Topographies of Fascism: Habitus, Space, and Writing in Twentieth-Century Spain (Toronto, 2013). 
possessions aligned with autarchic plans, and these three elements defined Fascism as "authoritarian modernity." 87

Libyan soil transformation summed up illiberal, totalitarian, alternative, aesthetic, and authoritarian socio-ecological modernities.

\section{CERRADO SOILS UNDER AUTHORITARIAN PROGRAMS IN CIVIL-}

MILITARY BRAZIL (1964-1985)

Agronomic engineer and Minister of Agriculture Alysson Paulinelli, known as "the person who has reinvented Brazilian agriculture," 88 was one of three people awarded the 2006 World Food Prize for his "vital role in transforming the infertile Cerrado in Brazil into productive cropland." 89 During the ceremony, he retraced the steps to the conquest of the Cerrado and described the situation in the 1970s:

We were facing a dilemma, our fertile lands, where farming practice had a long tradition, were now completely occupied and, despite that, we were unable to meet national and international food demand. The increase of our urban population, the rocketing price of oil, the global issue of food scarcity, and the consequent rise of the market value of agricultural production forced us to find other outlets for farm produce, other alternatives.... The possibility of the transformation of the Cerrado: ... that could be the great way out. Perhaps the only feasible and rational one. ${ }^{90}$

This quote encompasses both the national and geopolitical dimensions of authoritarian soil transformation: it sets the political agenda and highlights the relevance of the Cerrado bioma in the process of making Brazil "an emergent global power" under civil-military governments. ${ }^{91}$ Soil represented the means by which to complete the authoritarian statecraft and nationbuilding processes via the establishment of an "inland empire" 92 and the enforcement of technocratic measures. The policies carried out under the military regime in the countryside brought about a civil-authoritarian political project to increase public power in the hinterland, challenge local

87 A. De Bernardi, Una dittatura moderna: Il fascismo come problema storico (Milano, 2001), 61-68; M. Farinelli, "Città nuove, colonizzazione e impero: Il caso di Fertilia," Passato e Presente 88 (2013): 57-82, 73-74.

88 "Conheça Alysson Paulinelli: O homem que reinvetou a agricultura no Brasil," https://www. sgagora.com.br/sg/conheca-alysson-paolinelli-o-homem-que-reinvetou-a-agricultura-no-brasil/ (last accessed 19 Nov. 2020).

$89 \mathrm{https}: / /$ www.worldfoodprize.org/en/events/laureate_award_ceremony/2006_ceremony/ (last accessed 19 Nov. 2020).

90 A. Paolinelli, "A conquista do Cerrado," speech delivered at the 2006 World Food Prize Ceremony in Des Moines, Iowa, http://www2.worldfoodprize.org/assets/laureates/2006/ paolinelli-laureate-comments.pdf (last accessed 10 Aug. 2010).]

91 República Federativa do Brazil, II Plano Nacional de Desenvolvimento 1975-1979 (Rio de Janeiro, 1974), 9.

${ }^{92}$ H. O. Sternberg, "'Manifest Destiny' and the Brazilian Amazon: A Backdrop to Contemporary Security and Development Issues," Conference of Latin American Geographers Yearbook 13 (1987): 25-35. 
authorities and elites, and halt emergent peasant mobilization. ${ }^{93}$ Land transformation acted to legitimate the regime since it was coupled with the national security doctrine and developmentalist ideas ${ }^{94}$ and was a tangible authoritarian "ideological arrangement" resulting from aggressive modernization policies and institutionalized land-grabbing. ${ }^{95}$ Following from these premises, soils were seeded with countless social, economic, financial, and scientific programs via political power and technological tools. Some of these programs were completely new, while others stemmed from previous schemes and a few were inherited from past regimes. The combination of soil and authoritarianism helped establish the mastodontic techno-political infrastructure and bureaucratic organization of the Brazilian federated state. The Cerrado ecological area became the authoritarian-planned soil par excellence and synthesized politics into agricultural yields. Plowing through tropical authoritarian soil-management practices, one unearths their constitutive strata of three distinct layers: underlying layers, including nation-wide programs; transitional layers, including programs that followed the movement of the agricultural frontier and reached the Cerrado at a later stage; and topsoil layers, providing the setting for specific savannah-oriented schemes (see image 4).

The authoritarian Brazilian revolution inscribed itself upon an underlying trajectory of socioeconomic development that implied the industrialization of southeastern states such as São Paulo and Minas Gerais, while pushing the agricultural frontier into the southern Amazon rainforest and the Cerrado. ${ }^{96}$ Within this organic and multifaceted modernization scheme, the government's growth projections for Brazilian agriculture can be summarized by its forecasts for the period 1974-1979: production was expected to increase by 55 percent, the use of fertilizers by 94 percent, and pesticides by 129 percent, and 25 percent more improved seeds would be planted. Related transformations would follow these trends: meccanization increasing by 101 percent, development of the electric grid and electrification by 936 percent, and irrigation system development by 49

${ }^{93}$ E. P. Reis, "Brazil: One Hundred Years of the Agrarian Question," International Social Science Journal 50, 157 (1998): 419-32, 420, 426-27.

${ }^{94}$ N. Schneider, Brazilian Propaganda: Legitimizing an Authoritarian Regime (Gainesville, 2014), 5-6, 51.

95 G.F.T. Prieto, "The Alliance between Land and Capital during the Brazilian Dictatorship," Mercator, Fortaleza 16 (2017): 1-14, 1, 6.

${ }^{96}$ M. de Paiva Abreu, A Ordem do Progresso (São Paulo, 1990); A. B. de Castro and F.E.P. de Souza, A Economia Brasileira em Marcha Forçada (São Paulo, 2004); J. P. Macarini, "A política econômica do Governo Médici: 1970-1973," Nova Economia 15, 3 (2009), https://revistas.face. ufmg.br/index.php/novaeconomia/article/view/458 (last accessed 22 July 2020); F. Giambiagi, ed., Economia Brasileira Contemporânea (Rio de Janeiro, 2011); J. P. dos R. Velloso, "Estratégia de Desenvolvimento e o Programa de Integração Nacional," Revista Do Serviço Público 105, 2 (2017): 15-30. 


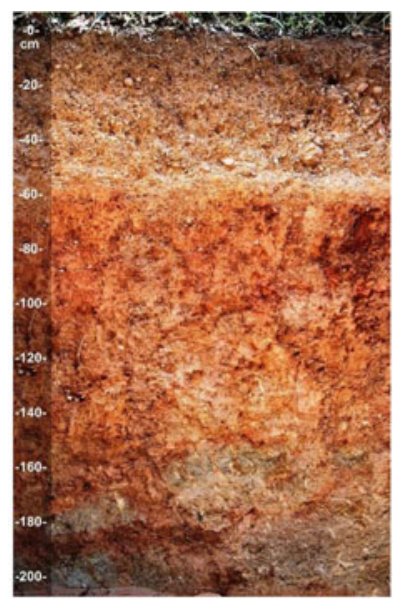

Scientific cooperation between Brazil and USA

Integrated Credit Program (ICP) - 1971

Settlement Program of Alto Paranaiba (PADAP) - 1972

Development of the Midwest Region (POLOCENTRO - Cerrados) - 1974

Program of Japanese-Brazilian Cooperation for the Cerrado Development (PRODECER) - 1978

Brazilian Soil Classification System (SiBCS)

Brazilian Agricultural Research Company (Empresa Brasileira de Pesquisa

Agropecuária, EMBRAPA)

RADAMBRASIL. Project

Ibec Research Institute (IRI)

National Association for Fertilizer Diffusion (Associação Nacional para Difusẫo

de Adubos, ANDA)

Government Economic Action Plan (Plano de Ação Econômica do Governo,

PAEG) - 1964

Goals and Bases for Government Action (Plano Metas e Bases para a Ação do

Governo, MBAG) - 1970

National Development Plan I and II (Planos Nacionais de Desenvolvimento, PND)

- 1972-1974: 1975-1979

Environmental Protection Laws

IMAGE 4: Developmental programmes on tropical soils in the Brazilian Cerrados. Image elaborated by the authors. Source of the original photo of the section of Cerrado soil: I. F. Lepsch, "Status of Soil Surveys and Demand for Soil Series Descriptions in Brazil," Soil Horizons 54, 2 (2013), https://dl.sciencesocieties.org/publications/sh/articles/54/2/sh2013-54-2-gc (last accessed 19 Nov. 2020).

percent. Complementary technological and scientific investment would grow by 71 percent. $^{97}$

Four main documents outlined the guidelines for nationalizing "peripheral areas"- the northeast, Amazonian, and center-west regions - by intensifying agricultural production: the 1964 Government Economic Action Plan (Plano de Ação Econômica do Governo, PAEG), ${ }^{98}$ the 1970 Goals and Bases for Government Action (Plano Metas e Bases para a Ação do Governo, $M B A G),{ }^{99}$ and the first and second National Development Plans (Plano Nacional de Desenvolvimento I and II, PND 1972-1974; 1975-1979). ${ }^{100}$ According to these documents, Cerrado soils would undergo a hybrid modernization that would be driven mostly by the federal state but pragmatically open to private and international investments regulated by forces of supply and demand. The goal was to level the uneven distribution of infrastructure, population, and production among Brazilian states, to fill a

97 República Federativa do Brazil, Plano Nacional I and II.

98 "Programa de Ação Econômica do Governo 1964-1966," documentos EPEA-no. 1 (Rio de Janeiro, 1964). For an analysis of the Plan, see E. F. Bastian, "O PAEG e o plano trienal: uma análise comparativa de suas políticas de estabilização de curto prazo," Estudos Econômicos (São Paulo) 43, 1 (2013): 139-66.

99 República Federativa do Brazil, Plano Metas e Bases para a Ação do Governo (Brasília, 1970).

${ }^{100}$ República Federativa do Brazil, Plano Nacional I and II. 
supposed vacuum. ${ }^{101}$ Behind these proclaimed goals, however, "filling demographic vacuums" also served to establish social order, political stability, and national security. They represented a strategic means to break the back of the Araguaia guerilla movement rooted in the peasant population, which took on a decisive role in the resistance to military repression. The greatest movement of armed resistance was mounted between 1967 and 1974 where the Amazon meets the Cerrado in the southeast of Pará and the north of Goiás, in the present states of Tocantins and Maranhão. Influenced by the Chinese rural guerrilla movement, a relatively small group of men and women challenged the dictatorship and, in so doing, made the government determined to occupy interior areas. The expansion of agriculture became a fundamental strategy for stabilizing control there. ${ }^{102}$ During the 1970 s and 1980 s, this strategy saw millions of families displaced from the northeast and the south to the country's midwestern and northern regions. The opening of new frontiers was carried out not only by allotting land to poor families, but also through incentives that funded the appropriation of large areas of land by urban companies and landowners from the mid-south. Expulsions and threats of eviction created pressure on tenants, squatters, small family-based producers, traditional and Maroon communities, and the region's indigenous peoples. ${ }^{103}$

Always at a national level, a series of environmental protection measures were passed: the Forest Code in 1965, the Fishing Activity Law in 1967, the Wildlife Protection Act in 1967, and the National Environmental Policy Law in $1981 .{ }^{104}$ This legislation, informed largely by international pressures, contradicted national developmental efforts but shaped political and social functions of land toward environmental protection. Environmental protection has been argued by authoritarian regimes as "part of modern rational development," and as such vast Amazonian conservation areas have been inaugurated under their rule. In the late 1980s conservation parks had an awkward presence among immense dams and mines. Not only were these parks demarcated as places to conserve a particular physical concept of the "Amazonian Environment," but they also became places to

\footnotetext{
${ }^{101}$ For developmental strategy as a bulwark of defense against communism, see Acker, Volkswagen, 7.

102 R. P. Machado, Brazilian History: Culture, Society, Politics 1500-2010 (Cambridge, UK, 2017), 323; J. de Almeida Teles, "The Araguaia Guerrilla War (1972-1974): Armed Resistance to the Brazilian Dictatorship," Latin American Perspective 44, 5 (2017): 30-52.

103 S. Sauer, "Soy Expansion into the Agricultural Frontiers of the Brazilian Amazon: The Agribusiness Economy and Its Social and Environmental Conflicts," Land Use Policy 79 (2018): 326-38, 328, 336.

${ }_{104} 1965$ Forest Code; 1967 Fisheries Law (Decree-Law no. 221/1967); 1967 Wildlife Protection Act (Decree-Law no 5.197/1967); 1981 National Environmental Policy Law (DecreeLaw no. 6.938/1981).
} 
contain and constrain ideas of "indigenous people," adding a racialized axis to the defining powers that shaped this distinct spatial landscape. ${ }^{105}$ Amazonia and the Cerrado were both initially affected by developmental plans, but international attention to "saving Amazonia," as Acker has shown, also directed development strategies toward the Cerrado, ${ }^{106}$ where the need for preservation was less apparent.

The significance of the Cerrado, and specifically its soil, as a geopolitical asset also came into focus with the 1973 Oil Crisis, created when Arab nation embargoed fuel exports to nations thought to be supporting Israel. Since Brazil imported about 90 percent of its petroleum, the 1973 oil shock would have been fatal for the country's astonishing economic growth had President General Ernesto Geisel not taken immediate action and supported the development of basic industries, while pushing for an expansion of farming activities rather than subsidizing middle-class consumption. This crisis also drove the government to envision Brazil not only as self-sufficient in terms of raw materials but also as an exporter of products from its rich asset, the soil. $^{107}$

Another contextual element that affected the history of the Cerrado under military rule was an increase in investments in and demands for research by scientific agricultural agencies. As we have argued, the dictatorial state apparatus was constructed partly based on soil. Scientists and technicians initiated an elaboration of a national soil classification and investigation in 1964, when agrarian expert Marcelo Camargo and FAO adviser Jacob Bennema presented a first categorization. Those initiatives led to the establishment of institutes that gained momentum during the 1970s. In 1975, a taxonomy of Brazilian soils was published, and in 1978 the first Brazilian Meeting on Soil Classification and Correlation was held, with the goal of

105 S. B. Hecht, "Soybeans, Development and Conservation on the Amazon Frontier," Development and Change 36, 2 (2005): 375-404, 395-96; N. C. Cavalho de Oliveira and C. Gomez Florentin, "Hydroelectric Dams and the Rise of Environmentalism under Dictatorship in Brazil and Paraguay (1950-1990)," in S. Brain and V. Pál, eds., Environmentalism under Authoritarian Regimes: Myth, Propaganda, Reality (Routledge, 2018), 51-74.

106 M. Lahsen, M.M.C. Bustamante, and E. L. Dalla-Nora, "Undervaluing and Overexploiting the Brazilian Cerrado at Our Peril," Environment: Science and Policy for Sustainable Development 58, 6 (2016): 4-15; C. M. da Silva, "Between Fenix and Ceres: The Great Acceleration and the Agricultural Frontier in the Brazilian Cerrado," Varia Historia (Belo Horizonte) 34, 65 (2018): 409-44.

107 F. H. de Mello, "Economic Policy and the Agricultural Sector in Brazil," Socioeconomic Change in Brazil 15, 2 (1978): 195-222; C. Lessa, A Estratégia de Desenvolvimento 19741976: Sonho e Fracasso (São Paulo, 1998); M. Napolitano, "The Brazilian Military Regime, 1964-1985," Oxford Research Encyclopedia of Latin American History (Oxford, 2018), 9, https://oxfordre.com/latinamericanhistory/view/10.1093/acrefore/9780199366439.001.0001/ acrefore-9780199366439-e-413?print=pdf (last accessed 19 Nov. 2020); A. Acker, "A Different Story in the Anthropocene: Brazil's Post-Colonial Quest for Oil (1930-1975)," Past \& Present 249, 1 (2020): 167-211, 175-76. 
developing the Brazilian Soil Classification System (SiBCS). ${ }^{108}$ The information generated by the National Soil Survey and Conservation Service (SNLCS) provided the technical basis for several applications, including the reclamation of the Brazilian Cerrado for agricultural production and Ecological-Economic Zonings (EEZs) in many regions of the country. The accumulation of such knowledge, developed in partnership with universities and the Brazilian Institute of Geography and Statistics (IBGE), in the 1970s generated the Brazilian Soil Classification System, which led to the 1997 publication of a book that is now in its fifth edition. ${ }^{109}$

In 1972-1973, out of the National Department of Research and Experimentation (Departamento Nacional de Pesquisa e Experimentação DNPEA), a hub of the Brazilian research agencies, President Emílio Garrastazu Médici established the Brazilian Agricultural Research Company (Empresa Brasileira de Pesquisa Agropecuária, or Embrapa). ${ }^{110}$ Embrapa counted nine regional headquarters, seventy experimental stations, eleven real estate properties, and two national centers. ${ }^{111}$ It became the leading public research institution tasked with overseeing and supporting the transformation of national agriculture specifically in tropical areas. In 1975 Embrapa-Cerrado was created.

Furthermore, the National Development Plan II became feasible in peripheral areas thanks to technological breakthroughs. A remote-sensing platform, carried by a twinjet Caravelle flying at an altitude of 12 kilometers at some 690 kilometers per hour, placed unproductive soils populated by indigenous communities under the technological scrutiny of the Radar of the Amazon Project, or RADAM. Beginning in 1970, RADAM carried out an integrated survey of the natural resources of a 1,500,000 square kilometer area in and around the territory affected by the Trans-Amazonian Highway, and due to its success, the surveying was expanded to the rest of the country in 1975 under the name RADAMBRASIL Project. ${ }^{112}$ This survey collected data on mineral resources, soils, vegetation, and land use and provided, in the short term, "basic and necessary information to elaborate appropriate

108 L.H.C. dos Anjos et al., "History of Soil Survey and Evolution of the Brazilian Soil Classification System-SiBCS," Geophysical Research Abstract 16, EGU2014-16793 (European Geosciences Union General Assembly, 2014).

109 Embrapa Soils, Brazilian Soil Classification System (Rio de Janeiro, 2018), https://www. embrapa.br/en/solos/busca-de-publicacoes/-/publicacao/1094001/brazilian-soil-classificationsystem (last accessed 19 Nov. 2020).

110 Decree-Law no. 5.851/1972.

111 História da Embrapa, https://www.embrapa.br/memoria-embrapa/a-embrapa (last accessed 19 Nov. 2020).

112 J. Bezerra, The Brazilian Amazon: Politics, Science and International Relations in the History of the Forest (New York, 2016), 74; I. P. Escobar et al., "Reprocessamento digital das imagens SLAR geradas pelos Projetos RADAM e RADAMBRASIL, Projeto RADAM-D," Anais XII Simpósio Brasileiro de Sensoriamento Remoto (2005): 4395-97. 
actions to tackle backwardness in those areas."113 Soils were classified according to categories of suitability for agricultural use and responsiveness to fertility treatments. The Cerrado, labeled as the "empty" midwest, together with the Caatinga, appeared to be the most suitable spaces for expanding intensive agriculture, but only under the unalterable terms of "technification.", 114

Technification of Brazilian agriculture relied on the expertise of several research institutes gained over a decade and on a well-established cooperation with the United States. It meant overcoming the physical limits of these regions by introducing innovative techniques and transforming the genetics of plants and the chemical composition of soils. ${ }^{115}$ In 1972, Embrapa facilitated the transfer of expensive, specialized planting machines and no-till/direct-planting technology (zero tillage), reducing erosion, enhancing soil permeability for water infiltration, and increasing organic material in the soil. This federal investment led to the development of socalled miracle soy cultivars capable of tolerating the metal-heavy, nutrientpoor, acidic soils of the center-west with high levels of biological nitrogen fixation. ${ }^{116}$ In the early 1970 s, Ibec Research Institute (IRI) ${ }^{117}$ investigators conducted several experiments on plant development in the Cerrado and found that the main obstacle was a deficiency of phosphorus and nitrogen in the soil. They suggested that targeted treatments would boost production by up to 89 percent over untreated soils. ${ }^{118}$ From 1969 onward, the National Association for Fertilizer Diffusion (Associação Nacional para Difusão de

113 República Federativa do Brazil, Plano Metas e Bases, 89.

114 Ibid.; Instituto Brasileiro de Geografia e Estatistica, Surveying of Natural Resources Series (RADAMBRASIL) (Rio de Janeiro, 1973), vol. 2, 89, 164.

115 R. Nehring, "Yield of Dreams: Marching West and the Politics of Scientific Knowledge in the Brazilian Agricultural Research Corporation (Embrapa)," Geoforum 77 (2016): 206-17; C. M. da Silva, "De um Dust Bowl paulista à busca de fertilidade no Cerrado: a trajetória do IRI Research Institute e as pesquisas em ciências do solo no Brasil (1951-1963)," Revista Brasileira de História da Ciência 5, 1 (2012): 146-55; P. A. Sanchez, Properties and Management of Soils in the Tropics (Cambridge, UK, 2019), 69-81.

116 R. D. Garrett and L. L. Rausch, "Green for Gold: Social and Ecological Tradeoffs Influencing the Sustainability of the Brazilian Soy Industry," Journal of Peasant Studies 43, 2 (2016): 461-93, 465-67.

117 The IRI was established in 1946 and stemmed from Nelson Rockefeller's profit and nonprofit enterprises in Latin America. It became independent in 1950, although it remained strongly influenced by U.S. research institutes and for-profit companies. The IRI experience was, however, relevant in the institutionalization of national research in agriculture and led to the establishment of the Embrapa. See C. M. da Silva, "From the Coffee Research to the Campos Cerrados' Experience: The Work of the IRI Research Institute (IRI) in Brazil (19461963)," (2016), https://lisbon2016rh.files.wordpress.com/2015/12/onw-0241.pdf (last accessed 19 Nov. 2020); da Silva, "Between Fenix and Ceres."

118 J.R.A. Monteiro et al., Nutrients Affecting Plant Growth in Cerrado (Separata) Soils. Embrapa Southeast Livestock (Brasília, 1975), 32; W. J. Goedert, "Avaliação agronómica de fontes de fósforo para a região dos cerrados," Relatorio Tecnico Anual do Centro de Pesquisa Agropecuaria dos Cerrados 1982/1985 (Planaltina, 1987), 122-29. 
Adubos, ANDA), a joint venture of fourteen private firms, ${ }^{119}$ tested the adaptability of rice, corn, beans, and cotton to the southern regions of Goiás, Minas Gerais, and, in a second stage, Mato Grosso. From five hundred initial demonstration sites, by 1975 the experiment had expanded to include three thousand fields. ${ }^{120}$

Even as the state became more proactive and inclined to centralize public control over agricultural experimentation, and even as presidents advocated for Brazil's national and international prestige, the country remained crucially dependent upon the United States. ${ }^{121}$ Scientific cooperation between North Carolina State University, the U.S. Agency for International Development (USAID), ${ }^{122}$ and Brazilian agencies led to two agreements: In 1963 the International Soil Fertility Evaluation and Improvement Project began promoting limestone and fertilizer use, including by private industry, and funding new laboratories that adopted innovative techniques and more reliable statistical analyses. For example, in 1970 the Tropical Soil Research Project began experiments with potassium fertilizers. In 1975, a specific unit within Embrapa called the Cerrado Agricultural Research Center (CPAC), in collaboration with Brazilian universities and Cornell University and the University of North Carolina, encouraged the production of master's theses and doctoral dissertations on Cerrado fertility. ${ }^{123}$ Research on the nutrient status of Latin American soils was "the technical front" of the so-called War on Hunger financed by AID to increase agricultural production in developing nations. ${ }^{124}$

It took more than fifteen years to establish the techno-political success of transforming the infertile Cerrado into a region of arable soils, and there emerged a growing interest in the specifics of that transformation. Cerrado symposia were held during the 1960s and 1970s by the São Paulo State Research Support Foundation (Fundação de Amparo à Pesquisa do Estado

119 The fourteen private companies were: Benzenex, CBA, Hearts, Copebras, Fertibras, Granubras, IAP, Itaú, Manah, Murakami, Uimbrasil, Takenaka, Ultrafertile, and Zanaga. For more information about ANDA, see: http://anda.org.br/ (last accessed 19 Nov. 2020).

120 Monteiro et al., Nutrients, 27; S. W. Buol, "Soils and Agriculture in Central-West and North Brazil," Scientia Agricola 66, 5 (2009): 697-707.

${ }^{121}$ On Brazilian hybrid modernization processes in which western characters combined with an explicit national project, see A. Acker, “"The Brand that Knows Our Land': Volkswagen's 'Brazilianization' in the 'Economic Miracle,' 1968-1973,' Monde(s) 1, 5 (2014): 197-218. On the role of the private sector in supporting and financing dictatorial projects, see the documentary Cidadâo Boilesen, directed by Chaim Litewski (Imovision, 2009).

${ }^{122}$ USAID gathered together several small projects of United States international aid for agriculture, sanitation, et cetera, and stemmed from the Marshall Plan. See: https://www.usaid. gov/who-we-are/usaid-history (last accessed 19 Nov. 2020).

123 A. Scheid Lopes and L. R. Guimarães Guilherme, "Fertilidade do solo e produtividade agrícola," in R. F. Novais et al., eds., Fertilidade do solo (Viscosa-M. G., 2007), 32.

124 "The Technical Front: Nutrient Status of Soils in Latin America," in War on Hunger: A Report from The Agency for International Development, vol. III, no. 1 (Jan. 1969): 10-15, 12-15. 
de São Paulo), the National Research Council (Conselho Nacional de Pesquisas), and the Brazilian Academy of Sciences (Academia Brasileira de Ciências). We can trace how a purely academic interest opened the way to more productivist approaches. While in the first and second congresses (1961 and 1965) presentations dealt with chemical and botanical issues, in the third and fourth (1971 and 1977) the focus was overwhelmingly on agronomic experimentation. ${ }^{125}$

The government's final step in creating an authoritarian Cerrado was to increase its cooperation with agro-entrepreneurs and financial institutes. A stratification and juxtaposition of agricultural credit support schemes sought to increase production, build facilities and infrastructure, offer technical assistance, and introduce chemical fertilizers. These schemes were the Integrated Credit Program (ICP) launched in 1971 by the Minas Gerais Development Bank (BDMG), the Settlement Program of Alto Paranaíba (PADAP) in 1972, the Development of the Midwest Region (POLOCENTRO-Cerrados) in 1974, and the Program of JapaneseBrazilian Cooperation for the Cerrado Development (PRODECER) in 1978. ${ }^{126}$ Those who benefitted from their subsidies were middle-class farmers and private owners with enough capital to face the challenge of the agricultural frontier. Most were second- or third-generation Japanese or Italians, or migrants, though some were descendants of the old plantation owners in coffee states like Minas Gerais and São Paulo.

The two decades of authoritarian supervision, allied with national liberal groups and close to the United States, was until recent times deemed a virtuous model for tropical agriculture. ${ }^{127}$ This model achieved the massive transformation of the Cerrado into the country's breadbasket. The introduction of the soybean represented an additional rupture with the past, and it remains the most prominent legacy of the authoritarian reforms. ${ }^{128}$ Rapid expansion of cultivation began in the 1960s, when soybeans were planted in the summer season and rotated with wheat in the winter (legumegrass crop rotation), which optimized land use and investments in agricultural machinery. Another driving force for the advance of soybeans in Brazil at that time was the exceptionally high price of the commodity on the

125 E. M. Ribeiro, E. M. Galizoni, and F. M. Galizoni, "Expansão da agropecuária e terras comuns: quatro casos nos cerrados de Minas Gerais," in Anais do XLIII Congresso Brasileiro de Economia e Sociologia Rural (SOBER) (Ribeirão Preto, 2005), 19.

126 D. G. Pereira, "Conquest of Cerrados: Reaping Results in Brazil," Foreign Agriculture 15, 20 (16 May 1977): 14-15; W. R. Nester, Japan and the Third World: Patterns, Power, Prospects (London, 1992), 260-63; Klink and Moreira, "Past and Current Human Occupation," 75-78.

127 "Tough Times for Embrapa, a Jewel of Brazilian Innovation,” Economist, 30 June 2018, https:/www.economist.com/the-americas/2018/06/30/tough-times-for-embrapa-a-jewel-ofbrazilian-innovation (last accessed 19 Nov. 2020).

128 L. L. Rausch et al., "Soy Expansion in Brazil's Cerrado," Conservation Letters (Aug. 2019): $1-10$. 
world market in the mid-1970s; in 1973 the legume reached an all-time high of US\$474.00 per ton. ${ }^{129}$

Finally, the military governments promoted a "conservative modernization in the Brazilian countryside," which enabled agricultural capital to take over the Brazilian midwest, first by transforming the large estates in rural enterprises and developing agro-industrial grain processing, and then by successfully adding livestock to the crop rotation. ${ }^{130}$ Such changes imposed both new land ownership patterns and a politics of racial supremacy, and severely affected the indigenous population. ${ }^{131}$ The National Truth Commission (Comissão Nacional da Verdade) investigated human rights violations during the period of 1946-1988 and recorded more than 8,500 indigenous people murdered during the agricultural expansion into the Brazilian west. ${ }^{132}$

\section{O NCLUSIONS}

This paper has shown the intimate connection between the far right and soil in the twentieth century by exploring place-based dictatorial narratives, governmental projections, and guidelines for the nationalization of peripheral areas through agricultural expansion and colonial appropriation. Methodologically, soils and political regimes have served as pivot points for our comparison between Italy and Brazil. By approaching authoritarianisms as political formations through their soil transformations we have elucidated ecological dynamics in the development of sociopolitical systems. We have described how soils, in connection with fertility and production, were mobilized by the Fascist regime in Libya and within the developmentalist strategy of the Brazilian authoritarian regimes between the 1960s and the 1980 s as symbols of and material spaces for their different modernizing missions. Both strategies included internal contradictions.

Within the environmental history and STS frameworks, analyses of soil transformations and their long-term effects avoid social reductionism and depoliticizing perspectives; they unfold "the multiple-scaled interconnections

129 US\$474.00/ton is equivalent to US\$1249.00/ton today, adjusted for inflation, according to the Chicago Board of Trade. A. J. Cattelan and A. Dall'Agnol, "The Rapid Soybean Growth in Brazil," OCL 25, 1 (2018), https://www.ocl-journal.org/articles/ocl/full_html/2018/01/ocl170039/ ocl170039.html (last accessed 19 Nov. 2020).

130 J. De Souza Martins, "O tempo da fronteira retorno à controvérsia sobre o tempo histórico da frente de expansão e da frente pioneira," Tempo Social: Revista de Sociologia da USP 8, 1 (1996): 25-70; B. Mueller and C. Mueller, "The Political Economy of the Brazilian Model of Agricultural Development: Institutions versus Sectoral Policy," Quarterly Review of Economic and Finance 62 (2016): 12-20, 17-18; A. R. de Oliveira, L.C.G. Ferreira, and B. Garvey, “A ocupação do Cerrado goiano pelo agronegócio canavieiro,” Revista NERA 42 (2018): 79-100, 79-80.

131 C. Ciccarone, "The Guarani Farm: Indigenous Narratives about Removal, Reclusion and Escapes during the Military Dictatorship," Brazil Vibrant: Virtual Brazilian Anthropology 15, 3 (2018), https://doi.org/10.1590/1809-43412018v15n3d511; C. M. da Silva, "The Miracle of the Brazilian Cerrados," Hispanic Issues Online 24 (2019): 98-116, 101.

132 Comissão Nacional da Verdade, Relatório. Volume II, Textos Temáticos (Brasília, 2014). 
and reciprocally constitutive processes between social relations and soil dynamics." 133 Our authoritarian soils are two "new natures"- to adopt a term from Dolly Jorgensen, Finn Arne Jorgensen, and Sarah Pritchard - and in the twentieth century the search for improvement has translated itself into fixes mediated by science and technology. In Libya, modernization relied on the construction of an extensive electric grid to pump water from underground and to power machinery. When the fuel and electrical supply started to run out during World War II, most farms were no longer able to produce and so were abandoned. In order to modify desert soils, in-loco farmers, officials, and agrarian technicians engaged in a war against natural constraints. In Brazil, the military-civilian vision and construction of a new nature came from outside, with remote sensing technology speeding up the scanning of vast regions, and the very nature of tropical soil was modified via a massive use of fertilizers, improved seeds, and pesticides. During the twentieth century, the boundary between natural ecofact and human-made artefact became progressively more blurred, and we have tracked this evolution through our two cases. ${ }^{134}$

In this paper we have given less attention to human resistance to these state directives to focus in on the role of soil in societies. Our argument here is that there are such things as authoritarian soils and soil-based authoritarian states. Several studies have explored the authoritarian remaking of nature, ${ }^{135}$ and another body of literature has stressed the presence of strong rural agendas in dictatorial governments. ${ }^{136}$ We have specifically attributed the development of twentieth-century dictatorships to agricultural practices and soil transformations.

The restoring and maintenance of fertility has been a crucial theme in the reactionary modernist projects of authoritarian regimes: soil is the element that reconciled the seemingly paradoxical coexistence of technological and

\footnotetext{
133 Engel-Di Mauro, Ecology, 11-12.

${ }^{134}$ M. Reuss and S. H. Cutcliffe, The Illusory Boundary: Environment and Technology in History (Charlottesville, 2010).

135 M. Armiero and W. Graf von Hardenberg, "Green Rhetoric in Blackshirts: Italian Fascism and the Environment," Environment and History 19, 3 (2013): 283-311; E. Swyngedouw, "Not a Drop of Water...': State, Modernity and the Production of Nature in Spain, 1898-2010," Environment and History 20 (2014): 67-92; M. Armiero, ed., "Fascism and Nature," special issue of Modern Italy 19, 3 (2014); S. R. Hamilton, "Environmental Change and Protest in Franco's Spain, 1939-1975," Environmental History 22 (2017): 257-81; S. Gorostiza, “"There Are the Pyrenees!' Fortifying the Nation in Francoist Spain," Environmental History 23, 4 (2018): 797-823, 797-82.

136 L. S. Jarvis, Chilean Agriculture under Military Rule: From Reform to Reaction 1973-1980 (Berkeley, 1985); L. F. Prieto, J. Pan-Montojo, and M. Cabo, eds., Agriculture in the Age of Fascism: Authoritarian Technocracy and Rural Modernization, 1922-1945 (Turnhout, 2014); L. Cambupí, Engineers and the Making of the Francoist Regime (Cambridge, Mass., 2014), 77102; R. Costa, From Dictatorship to Democracy in Twentieth-Century Portugal (London, 2016), 44-77.
} 
scientific innovation and social ruralism and traditionalism. As others have argued with regard to the Eastern European communist authoritarianisms, the transformation of agriculture meant "a major step towards the creation of the envisaged utopian ... society in the countryside, and dogmatically praised the heroism of the peasantry, who allegedly responded to the.... Party's call and prevailed upon the regime's enemies in rural areas." ${ }^{137}$ Not just farmers were important - soil also bound other social groups to the state, including scientists, public servants, and investors and speculators. In a complementary fashion, the state encompassed different social groups under the umbrella of a corporatist society to work toward the overriding, manifold purpose of increasing productivity. Through soil fertility, reactionary states redefined and drew new boundaries of the nation, both geographically and socially. The rhetorical tool of "unoccupied" and "insufficiently occupied" lands highlights another common element: the states' complete disregard for how populations that had long lived on the land used it or related to ecological conditions on the ground. Such approaches, particularly when they were imposed in peripheral regions, spawned racialized societies. ${ }^{138}$

Moving from our empirical cases, we infer that cultivated soils offer dictatorships the material space in which to develop and condense quintessential attributes of dictatorships: social order, political stability, national security, geopolitical prestige, and the denial of conflicts. Free from any liberal or democratic constraints and relying on the assumption that everything is within the state and that the state guides and synthesizes every aspect of society, totalitarianisms legitimize specific visions of environmental transformation, especially modernist ones. From the totalitarian perspective, marginal areas represent testing grounds and experimental sites for analyses of political, social, economic, financial, technological, and scientific initiatives and programs. Free from most institutional checks and competition for political power, authoritarian states are able to mobilize huge assets in terms of both human expertise and money, even in economically challenging times. Indeed, it was due to their cash-strapped situations that Italian Fascists and Brazilian militarists counted on agricultural activities to help them achieve social control and build consent. The transformation of desert and savannah regions into fields promised future prosperity to poor rural families and the faith in national economic growth justified significant investments, violence, and the displacement of peoples. For nationalistic

137 A. Bauerkämper and C. Iordachi, "The Collectivization of Agriculture in Eastern Europe: Entanglements and Transnational Comparisons," in C. Iordachi and A. Bauerkämper, eds., Collectivization of Agriculture in Communist Eastern Europe: Comparison and Entanglements (New York, 2014), 6.

138 Fantoli, La siccitá in Libia, 121-27, 184-87; E. Robertson, "Race as a Factor in Mussolini's Policy in Africa and Europe," Journal of Contemporary History 23, 1 (1988): 37-58, 40-41; Sauer, "Soy Expansion," 328. 
purposes and from a geopolitical perspective, agricultural development schemes also represent strategies for reacting to international sanctions and global energy crises. They showcase national power, define a self-sufficiency oriented political economy, and boost large-scale aggressive expansionism.

The goal of showcasing conflictual zones, linked to racialized disparities and corporatism, involved both the material and immaterial spheres. Authoritarian soils are also made up of words, and verbal constructions became common beliefs that were ingrained into Italian and Brazilian societies: in both of these cases we find powerful rhetorics of emptiness and miracles. The ideological construct of emptiness is a recurring theme in the history of colonialisms. ${ }^{139}$ Though an established corpus of scholarship has deconstructed the colonial fallacy of "the empty land," the actuality and materiality of emptying processes and acts of ruination have remained on the margins of this critical effort. ${ }^{140}$ Very little has been written about the sixteen Libyan concentration camps that operated between 1930 and $1933,{ }^{141}$ or how the Fascist war against indigenous fauna and non-cultivated plants flowed from the construction of the rhetoric of an empty Libya. If we examine how states focused on fertility, and the function that high demographic rates played in the occupation and appropriation of spaces, we find that women were classed as reproductive beings, like plants, whose task was to fill desolate wastelands with humans. Despite the pervasive myth of productivity and the valorization of resources, agricultural colonization dynamics can only be understood with reference to uneven power relations and inequalities.

Authoritarian soils leave much longer legacies than do democratic ones due to the absence of contradictory visions in historical sources and contemporary narratives. The myth of agricultural productivity is tied to the enduring rhetoric of the miracle. Portrayals of crop production in unsuitable soils as a "miracle" outlived the authoritarian regimes that founded them and remained for decades after, and contesting this idea is crucial to critically reconstructing the building up of soil fertility as a mirror of authoritarianism. With regard to the agricultural sector, it has been problematic to question the positive role and civilization effort attached to dictatorial reclamation schemes, particularly in avowedly empty colonial spaces. Agricultural

139 J. Holston, The Modernist City: An Anthropological Critique of Brasilia (Chicago, 1989), 14-20; A. Sluyter, Colonialism and Landscape: Postcolonial Theory and Applications (Lanham, 2002), 6, 189-90; M. W. Ertsen, "Colonial Irrigation: Myths of Emptiness," Landscape Research 31, 2 (2006): 147-67; R. L. Nelson, "Emptiness in the Colonial Gaze: Labor, Property, and Nature," International Labour and Working-Class History 79, 1 (2011): 161-74.

${ }^{140}$ N. Leshem, "Repopulating the Emptiness: A Spatial Critique of Ruination in Israel/ Palestine," Environment and Planning D: Society and Space 31, 3 (2013): 522-37, 522.

${ }^{141}$ N. Labanca, "Italian Colonial Internment," in R. Ben-Ghiat and M. Fuller, eds., Italian Colonialism (New York, 2005), 27-36. 
enterprises within developmentalist frameworks were celebrated in democratic times in both Italy and Brazil. ${ }^{142}$

Those two histories are "a metaphor for nonsustainability": ${ }^{143}$ they shed critical light on development pathways that are widely accepted as success stories when in fact they undermined the goals of furthering human and environmental sustainability. In this paper we have asserted that these schemes must be placed within a framework of social oppression and ecological unsustainability in order to move forward the fascinating and urgent discussion about the relationship between agriculture, development, and democratization. ${ }^{144}$

142 R. Musu, director, Dal Deserto alla Vita (Incom documentary film, 1951); J. Dubois, "La colonizzazione italiana in Libia," Africa: Rivista trimestrale di studi e documentazione dell'Istituto per l'Africa e l'Oriente 10, 10 (1955): 287-89; Micale, Agricoltura $e$ decolonizzazione, 70; P. Ballinger, Borders of the Nation, Borders of Citizenship: Italian Repatriation and Redefinition of National Identity after World War II, Comparative Studies in Society and History 49, 3 (2007), 713-41; P. Cremaq, "Brazilian Agriculture: The Miracle of the Cerrado," Economist, 26 Aug. 2010; N. Rada and C. Valdes, "Policy, Technology and Efficiency of Brazilian Agriculture," United States Department of Agriculture-Economic Research Report 137 (July 2012); N. Rada, “Assessing Brazil's Cerrado Agricultural Miracle,” Food Policy 38, 1 (2013): 146-55.

143 Lahsen, Bustamante, and Dalla-Nora, "Undervaluing and Overexploiting," 14.

144 P. P. Houtzager and M. J. Kurtz, "The Institutional Roots of Popular Mobilization: State Transformation and Rural Politics in Brazil and Chile, 1960-1995," Comparative Studies in Society and History 42, 2 (2000): 394 424; P. Brassley, Y. Segers, and L. Van Molle, eds., War, Agriculture, and Food: Rural Europe from the 1930s to the 1950s (New York, 2012); C. Martiin, J. Pan-Montojo, and P. Brassley, Agriculture in Capitalist Europe, 1945-1960: From Food Shortages to Food Surpluses (London, 2016); H. Thomson, Food and Power: Regime Type, Agricultural Policy, and Political Stability (Cambridge, UK, 2019). 
Abstract: This article analyzes the role of soil in the making of authoritarian regimes and illustrates twentieth-century practices and discourses related to fertility across the globe. It compares two different approaches to and understandings of soil fertility: the first emerged in North Libya under Italian Fascist rule (1922-1943), the second in Central Brazil during the civil-military dictatorship (1964-1985). We compare two soil-forming processes that changed physical and chemical properties of the original matter and were embedded within specific ideologies of modernization. In both cases, state agendas of agrarian production played a paramount role not only in socioeconomic projects but also as an instrument to suppress opposition. Technocratic and political aspects of building and maintaining fertility were interwoven, although in different patterns in the two countries. We show how the rejuvenation of land bled into the regeneration of communities through processes that anchored the self-definition and development of these authoritarian regimes, and argue that attempts at landscape transformations through agricultural activity and strategies of fertilization are inescapable features of dictatorships. In so doing, we elaborate the concept of "authoritarian soil." The juxtaposition of these non-synchronous cases reveals how agricultural modernization developed throughout the twentieth century. Our study is rooted in environmental history and contributes to the ongoing dialogue between that field and science and technology studies. Its crosstemporal, comparative methodology draws upon sources and historiographical debates in English, Italian, and Portuguese.

Key words: environmental history, colonialism, soil, agriculture, Cerrado, authoritarian regimes, Italian fascism, civil-military dictatorship, Libya, Brazil 